Document downloaded from:

http://hdl.handle.net/10251/65582

This paper must be cited as:

Mollá Romano, S.; Compañ Moreno, V. (2015). Nanocomposite SPEEK-based membranes for Direct Methanol Fuel Cells at intermediate temperatures. Journal of Membrane Science. 492:123-136. doi:10.1016/j.memsci.2015.05.055.

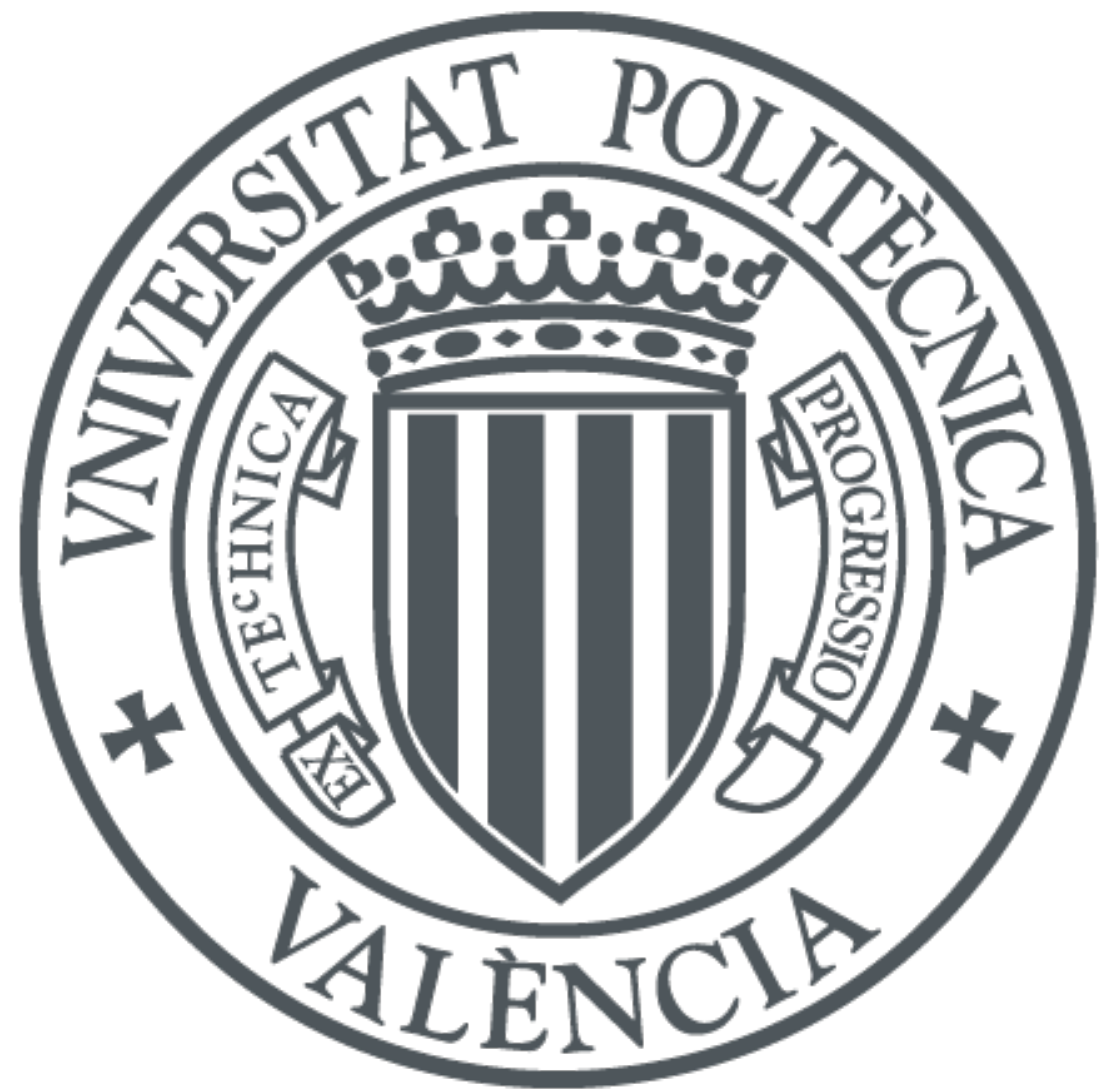

The final publication is available at

http://dx.doi.org/10.1016/j.memsci.2015.05.055

Copyright Elsevier

Additional Information 


\title{
Nanocomposite SPEEK-based membranes for Direct Methanol Fuel Cells at intermediate temperatures
}

\author{
Sergio Mollá, Vicente Compañ \\ Dpto. Termodinámica Aplicada, ETSII, Universidad Politécnica de Valencia, Camino de Vera s/n, 46022 - Valencia, \\ Spain.
}

\begin{abstract}
Novel nanocomposite membranes were prepared by infiltration of a blend of sulfonated PEEK (SPEEK) with polyvinyl alcohol (PVA), using water as solvent, into electrospun nanofibers of SPEEK blended with polyvinyl butyral (PVB). The membranes were characterized for their application on Direct Methanol Fuel Cells (DMFCs) operating at moderate temperatures $\left(>80^{\circ} \mathrm{C}\right)$. An important role of the solvent on the crosslinking temperature for the SPEEK-PVA system was observed. A mat of hydrated SPEEK$30 \%$ PVB nanofibers revealed a higher proton conductivity in comparison with a dense membrane of similar composition. Incorporation of the nanofiber mats to the SPEEK$35 \%$ PVA matrix provided mechanical stability, methanol barrier properties and certain proton conductivity up to a crosslinking temperature of $120^{\circ} \mathrm{C}$. Not remarkable effect of the nanofibers was found above that crosslinking temperature. The combined effect of the nanofibers and crosslinking temperature on the properties of the membranes is discussed. DMFC performance experiments concluded promising results for this new low-cost type of membranes, although further optimization steps are still required.
\end{abstract}

Keywords: Nanofibers, sulfonated PEEK, PVA, PVB, DMFC membranes.

*: Corresponding author: Tel.: +34-96-387 93 28; Fax: +34-96-387 79 24; E-mail address: vicommo@ter.upv.es 


\section{Introduction}

Direct methanol fuel cells (DMFCs) are electrochemical devices which can offer about ten times more energy density than hydrogen-fueled proton exchange membrane fuel cells (PEMFCs) and fifteen times higher than Li-ion batteries. This is explained by the liquid nature of the methanol fuel which additionally enables an easy refueling [1-3]. Nevertheless, it is well known that methanol crossover through the membrane, commonly a sulfonated perfluorinated polymer so-called Nafion ${ }^{\circledR}$, causes the DMFC performance to decrease. Methanol adsorbates on the catalyst active sites for oxygen reduction at the cathode is the main reason for performance deterioration [4,5].

Typically, inorganic (nano-)fillers are incorporated into Nafion ${ }^{\circledR}$ via physical or chemical procedures with the aim to block methanol crossover. Preferential sorption of water versus methanol and an increased path tortuosity for mass transport result in lower methanol permeabilities for the hybrid membranes [6-9].

The membranes require to be strong while tough and flexible in order to achieve long mechanical stability. However, introduction of inorganic particles after certain loadings can cause agglomeration and poor dispersion [10,11] and finally a critical embrittlement of the membrane is expected. A different strategy then involves physically, chemically or ionically blending/crosslinking Nafion ${ }^{\circledR}$ with a methanol barrier polymer such us polyvinyl alcohol (PVA), polyvinylidene difluoride (PVDF) and polybenzimidazole (PBI), although in this case proton conductivity is the most affected parameter [12-15].

A pore-filling electrolyte membrane was conceived to overcome the limitations of the polymer blended fuel cell membranes. Such membranes are composed of a polymeric porous substrate with pores on the submicrometer scale which are filled with a proton conductive polymer. The porous substrate must be completely inert to the fuel and mechanically strong to prevent excess swelling of the filling polymer, which can otherwise lead to high methanol crossover [16]. A limited number of materials can be processed to obtain porous frameworks, and among them stand out polyimide (PI) $[16,17]$, polytetrafluoroethylene (PTFE/Teflon ${ }^{\circledR}$ ) [18] and ultra-high molecular weight polyethylene (UHMWPE) [19]. Unfortunately, lack of functional groups and difficulty to functionalize the surface of those substrates can result in weak interfaces between both polymer phases thus affecting the long-term stability as it has been reported for a PTFE/Nafion ${ }^{\circledR}$ system [20].

Recently, a similar but more versatile approach enables the utilization of a wide range of materials for the preparation of porous substrates. This approach involves electrospinning a polymer solution to obtain a nanofiber mat which is afterwards filled with a proton conductive polymer matrix [21-28], although insulating polymers infiltrated into proton conductive nanofibers has also been proposed [29,30]. Interestingly, it has been found that proton conducting nanofibers exponentially increase conductivity with decrease in fiber diameter [25,31]. Higher increment of the proton conductivity is observed along the fiber axis direction than perpendicularly, which is attributed to the preferential orientation of the sulfonated polymeric chains and the consequent alignment of the ionic channels [21,22]. On the other hand, it has been suggested that proton transport takes place preferentially on the surface of the nanofibers, enriched with ionic clusters, rather than inside the nanofiber structure [32]. Probably, a plausible explanation for the enhancement of the proton conductivity of polymer electrolyte nanofibers involves both mechanisms.

Comparison between nanofiber- and blended-type membranes has been carried out with Nafion ${ }^{\circledR}$ and PVA. It was concluded that both types of membranes were 
effective to reduce methanol crossover, although the nanofiber morphology provided less tortuous proton conduction pathways and better DMFC performance than the blended membranes, in which agglomeration and non-homogeneous distribution of PVA occurred [26]. This is in agreement with the empirical evidence that DMFC performance is mainly governed by proton conductivity of the membrane. This is a consequence of methanol crossover to decrease with increasing current density, thus becoming ohmic losses the dominant parameter [33-35].

Chemical functionalization of the nanofiber surface offers a valuable strategy to improve interface compatibilization with the matrix, thus helping to further reduce methanol permeability and increase mechanical reinforcement and proton conductivity of the nanocomposite membranes [25,36]. Our group has pioneered the development of nanocomposite membranes incorporating surface functionalized nanofibers. We produced PVA nanofibers which were chemically modified on the surface with 4formyl-1,3-benzenedisulfonic acid groups, with the purpose to promote nanofibermatrix interaction via hydrogen bonding between sulfonic acid moieties and to assist the proton conduction, and subsequently Nafion ${ }^{\circledR}$ was infiltrated within the nanofiber mats. The resulting nanocomposite membranes were compact and contained a large fraction of PVA phase (approx. $50 \mathrm{wt} \%$ ), which caused about one order of magnitude reduction of methanol permeability while proton conductivity in comparison with pristine Nafion ${ }^{\circledR}$ was just slightly reduced due to the non-conducting behaviour of PVA. Interestingly, the strong reinforcement effect induced by the nanofibers enabled the preparation of very low thickness membranes with good mechanical properties and low ohmic resistances, which resulted in advantageous fuel cell performances [37-39].

Nafion ${ }^{\circledR}$ is an expensive material and intrinsically limited to temperatures below $80^{\circ} \mathrm{C}$ for an adequate performance $[40,41]$. Motivated by the replacement of Nafion ${ }^{\circledR}$ with a low-cost alternative polymer electrolyte able to operate at intermediate temperatures $\left(80-140{ }^{\circ} \mathrm{C}\right)$, suitable for efficient electro-oxidation of methanol and efficient catalyst utilization, our group investigated blended membranes of sulfonated poly-ether-ether-ketone (SPEEK) with a hydrophilic polymer, PVA, and a derived hydrophobic polymer, polyvinyl butyral (PVB) [42]. The purpose was to find optimal compositions for DMFC operation attending to their chemical stability in hot aqueous solutions (evaluated in boiling water). It was found that PVB constrained in a larger extent the water uptake and swelling when blended with SPEEK than PVA, and correspondingly, PVB was preferred for providing methanol barrier properties at the expense of a considerably lower proton conductivity. On the other hand, PVA was suitable for avoiding excessive swelling and dissolution of the blended membrane while permitting acceptable proton conductivities for fuel cell application. The best properties were exhibited by blends of SPEEK and PVA in a ratio of 65:35 w/w, SPEEK$35 \%$ PVA, and by SPEEK-30\%PVB compositions. SPEEK grades with values of ionexchange capacity (IEC) of $1.75 \mathrm{meq} \mathrm{g}^{-1}$ and $2.05 \mathrm{meq} \mathrm{g}^{-1}$ were used, respectively.

Furthermore, an additional goal was the replacement of the PVA nanofiber mats by proton conducting nanofibers simultaneously providing hindrance to methanol crossover. In this sense, the present work represents the research conducted on the preparation and characterization of novel nanocomposite membranes made from nanofiber mats of SPEEK-30\%PVB embedded in a SPEEK-35\%PVA matrix. A special focus has been laid on the DMFC performance of the nanocomposite membranes at intermediate temperatures.

\section{Experimental section}




\subsection{Materials}

Granulated SPEEK (FUMION E ionomers) with ion-exchange capacities of $1.75 \mathrm{mmol} \mathrm{g}^{-1}$ and $2.05 \mathrm{mmol} \mathrm{g}^{-1}$ were acquired from Fumatech $\mathrm{GmbH}$ (St. Ingbert, Germany). These IEC values were confirmed by the authors via titration of samples dissolved in water [42]. The SPEEK materials were dried at $100{ }^{\circ} \mathrm{C}$ for $24 \mathrm{~h}$ in vacuum atmosphere and stored in a sealed container to avoid absorption of water before the preparation of membranes.

Polyvinyl alcohol, Mowiol 28-99 grade PVA, and polyvinyl butyral, Mowital B75H grade PVB, were kindly donated by the company Kuraray Europe GmbH (Frankfurt, Germany).

N,N-Dimethylacetamide (DMAc) solvent was purchased from Acros Organics. PVA, PVB and DMAc were used as received. The chemical structures of SPEEK, PVA and PVB are represented in our previous paper [42].

\subsection{Preparation of membranes}

\subsubsection{SPEEK-35\%PVA membranes}

SPEEK with ion-exchange capacity of $1.75 \mathrm{meq} \mathrm{g}^{-1}$ was dissolved in boiling water. An appropriate amount of PVA was separately dissolved in water at $80^{\circ} \mathrm{C}(10 \mathrm{wt} \%$ PVA concentration) and then both solutions were mixed to prepare a SPEEK-35\%PVA composition (SPEEK/PVA 65:35 w/w). Water was added until reaching a $7.5 \mathrm{wt} \%$ polymer (SPEEK+PVA) concentration. The solution was vigorously stirred at room temperature until complete homogenization and the membranes cast overnight on a Teflon ${ }^{\circledR}$ Petri dish placed in an oven at $40^{\circ} \mathrm{C}$. Finally, the membranes were crosslinked at different temperatures, i.e. $110^{\circ} \mathrm{C}, 120^{\circ} \mathrm{C}, 130{ }^{\circ} \mathrm{C}$ and $140{ }^{\circ} \mathrm{C}$, for $1 \mathrm{~h}$ and immersed in boiling water for another $1 \mathrm{~h}$. The membranes were stored in water at room temperature.

\subsubsection{SPEEK-30\%PVB nanofibers}

A blended solution of SPEEK and PVB in a ratio of 70:30 w/w was prepared in DMAc solvent as follows: A certain amount of PVB was dissolved under stirring in DMAc at $80^{\circ} \mathrm{C}$ for $1 \mathrm{~h}$. When the solution cooled down to room temperature, a specific amount of SPEEK with ion-exchange capacity of $2.05 \mathrm{meq} \mathrm{g}^{-1}$ was incorporated. The mixture was heated again at $80{ }^{\circ} \mathrm{C}$ and vigorously stirred for $1 \mathrm{~h}$ until complete homogenization. Several polymer (SPEEK+PVB) concentrations were obtained, i.e. $12.5 \mathrm{wt} \%, 15 \mathrm{wt} \%$, $17.5 \mathrm{wt} \%$ and $20 \mathrm{wt} \%$.

Nanofiber mats of SPEEK-30\%PVB were electrospun (YFLOW SL, Málaga, Spain) from those prepared solutions. A potential difference of $35 \mathrm{kV}$ was applied between the needle and the planar collector, which were $25 \mathrm{~cm}$ apart, and a flow rate of $0.2 \mathrm{ml} \mathrm{h}^{-1}$ was fixed during the electrospinning process at a relative humidity (RH) below $40 \%$. An optimal solution for the electrospinning process was selected and used afterwards. Such a solution was electrospun for $15 \mathrm{~h}$ and the corresponding mats were heated at $160{ }^{\circ} \mathrm{C}$ for 30 minutes, in order to remove trapped DMAc molecules, and then crosslinked at $200^{\circ} \mathrm{C}$ during $1 \mathrm{~h}$ in an oven. Round steel frames were placed on the surface of the PVB nanofibers before the crosslinking reaction. The purpose is to pull tight the mats confined within the inner area of the frames as a consequence of their 
dimensional shrinking. The last step was to fix firmly the crosslinked nanofiber mats in the frames. This was achieved by the attachment of supplementary frames which were mounted on the reverse side of the laying frames.

\subsubsection{Nanocomposite SPEEK-based membranes}

A $7.5 \mathrm{wt} \%$ concentrated solution of SPEEK-35\%PVA in water was infiltrated into the SPEEK-30\%PVB nanofiber mats with the aim to form the matrix of the nanocomposite membranes. Our method involved the immersion for 5 minutes of the framed nanofibers inside the cited aqueous solution followed by evaporation of the water for other 5 minutes. This was carried out by introducing the soaked nanofiber mats in a climate chamber (INELTEC CCSR-0/50, Spain) at $90{ }^{\circ} \mathrm{C}$ with a very low humidity level. This process was repeated 4 times while the nanofiber mat was rotated $90^{\circ}$ in each step. In the final step, the formed nanocomposite membrane was dried during 10 minutes inside the climate chamber. Next, the membrane was cut along the frame boundary and further dried overnight at room temperature.

Finally, square membranes $\left(5 \times 5 \mathrm{~cm}^{2}\right)$ were cut and crosslinked for $1 \mathrm{~h}$ under a pressure of $1 \mathrm{kN} \mathrm{cm}^{-2}$ between the hot plates of a commercial hand press (Rondol, France). Four crosslinking temperatures were examined, i.e. $110^{\circ} \mathrm{C}, 120^{\circ} \mathrm{C}, 130^{\circ} \mathrm{C}$ and $140{ }^{\circ} \mathrm{C}$. The crosslinked nanocomposite membranes were introduced in boiling water for $1 \mathrm{~h}$ and stored in water at room temperature.

\subsection{Characterization of the nanocomposite membranes}

\subsubsection{Scanning electron microscopy (SEM) analysis}

The morphology of the SPEEK-30\%PVB nanofibers and the structure of the nanocomposite membranes were investigated using a scanning electron microscope (SEM-model JSM-5410, Jeol Co., Japan). The samples were gold coated before SEM observations.

For cross-sectional observations, the membranes were cut in a fragile rupture mechanism by previously freezing the samples within liquid nitrogen.

\subsubsection{Water uptake, swelling degree and ion-exchange capacity}

Water uptake was calculated from the difference between the weight of the nanocomposite membranes wet (hydrated after treatment in boiling water) and dry (dried at $100{ }^{\circ} \mathrm{C}$ in oven), according to the expression,

Water uptake $(\%)=\frac{m_{w e t}-m_{d r y}}{m_{d r y}} \times 100$

A value of water uptake was averaged from three similar membranes crosslinked at each temperature.

The swelling degree (in-plane) was measured by the change of area of square membranes with initial $5 \times 5 \mathrm{~cm}^{2}$ dimensions $\left(A_{0}=X_{0} \cdot X_{0}\right)$. After $1 \mathrm{~h}$ in boiling water, the swollen membranes practically maintained the square shape but with enlarged dimensions $\left(A_{f}=X_{f} \cdot X_{f}\right.$ ), see Equation (2). Similarly, swelling through the thickness was obtained from the difference between the membrane thickness in dry $\left(L_{0}\right)$ and wet $\left(L_{f}\right)$ states as in Equation (3), 
In- plane swelling $(\%)=\frac{A_{f}-A_{0}}{A_{0}} \times 100$

Thickness swelling $(\%)=\frac{L_{f}-L_{0}}{L_{0}} \times 100$

The ion-exchange capacity (IEC) was estimated from the swollen membranes, in acid form, by overnight immersion in a $2 \mathrm{M} \mathrm{NaCl}$ solution. The protons liberated during the exchange reaction $\mathrm{R}-\mathrm{SO}_{3} \mathrm{H}+\mathrm{Na}^{+} \rightarrow \mathrm{R}-\mathrm{Na}+\mathrm{H}^{+}$were titrated with a $0.01 \mathrm{M} \mathrm{NaOH}$ solution and phenolphthalein. The IEC was calculated from,

$\operatorname{IEC}\left(\right.$ meq $\left.g^{-1}\right)=\frac{V_{\mathrm{NaOH}} \times 0.01}{m_{d r y}}$

where $V_{\mathrm{NaOH}}$ and $m_{d r y}$ are the volume in millilitres of $\mathrm{NaOH}$ solution used during the titration of the protons released by $\mathrm{m}$ grams of dry membrane, respectively. The values of $m_{d r y}$ were measured after drying at $100{ }^{\circ} \mathrm{C}$ the samples utilized for the ion-exchange with $\mathrm{NaCl}$ solution.

\subsubsection{Infrared (IR) spectroscopy}

IR spectroscopy (Jasco FT/IR-6200 spectrometer, United States) was used to investigate the chemical reactions taking place within the nanocomposite membranes at each crosslinking temperature.

\subsubsection{Mechanical properties}

Static tensile strength testing (DMTA Q800 TA Instruments, United States) was carried out at $25^{\circ} \mathrm{C}$ using samples of SPEEK-35\%PVA and nanocomposite membranes both crosslinked at $120{ }^{\circ} \mathrm{C}$. Samples of $2 \mathrm{~mm}$ width were clamped under a torque of $0.113 \mathrm{~N} \mathrm{~m}^{-1}$, and the clamps were separated $10 \mathrm{~mm}$. The samples were subjected to a preload of $0.001 \mathrm{~N}$ and the speed rate was fixed at $1 \mathrm{~N} \mathrm{~min}^{-1}$. The thickness of the samples was calculated averaging five measurements at different parts. Previously, the membranes, stored in water, were superficially dried with a paper and pressed between two plastic sheets under a weight, which were afterwards placed inside an oven at $35^{\circ} \mathrm{C}$ during 4 days. Five samples of each type of membrane were tested and an average result reported.

\subsubsection{Methanol permeability}

A typical 2-cell experimental setup [43] was used to measure the coefficient of methanol permeability across the SPEEK-35\%PVA and nanocomposite membranes as a function of crosslinking temperature. The donor chamber (D) was filled with a $2 \mathrm{M}$ aqueous solution of methanol, while the receptor chamber (R) was filled with distilled water. Both chambers were stirred and heated at a fixed temperature of $60{ }^{\circ} \mathrm{C}$. The variation of methanol concentration with time in the receptor reservoir was determined by means of a densimeter (DMA $4500 \mathrm{M}$, Anton-Paar, Austria). A small sample of solution (approx. $1 \mathrm{ml}$ ) is introduced into a thermostated U-shaped borosilicate glass 
tube with a precise volume being excited to vibrate at its characteristic frequency, which depends on the total mass of the tube and sample. Through a precise determination of the characteristic frequency and a mathematical conversion, the mass density $\left(\mathrm{g} \mathrm{cm}^{-3}\right)$ of the sample can be estimated. Consequently, the methanol concentration of that sample can be mathematically given from a calibration curve of density versus methanol concentration which is previously obtained at the same measurement temperature $\left(50{ }^{\circ} \mathrm{C}\right.$ in our experiments).

During permeability experiments, samples from the receptor compartment were taken at certain time intervals and the density recorded. With the purpose to avoid the volume of solution in the receptor reservoir $\left(V_{R}=150 \mathrm{~cm}^{3}\right)$ diminishes after each measurement, the samples were recovered from the densimeter and introduced again into the compartment. Representing the methanol concentration in the receptor chamber $\left(C_{R}\right)$ versus time $(t)$, the apparent permeability $(P)$ of methanol across a membrane with thickness $L(\mathrm{~cm})$ and surface area $A\left(A=2.27 \mathrm{~cm}^{2}\right)$ can be determined from Equation (5). This is valid while the gradient $C_{D, 0}-C_{R}$ does not significantly change, that is, for the condition $C_{D, 0} \gg C_{R}$ (being $C_{D, 0}$ the initial methanol concentration in the donor chamber). The parameter $t_{0}$ is assigned to the time lag before the pseudo-steady state is reached,

$P=\frac{V_{R} \cdot L \cdot C_{R}}{C_{D, 0} \cdot A \cdot\left(t-t_{0}\right)}$

\subsubsection{Electrochemical impedance spectroscopy (EIS)}

The proton conductivities through thickness of the SPEEK-30\%PVB nanofibers and the prepared membranes were measured at $60{ }^{\circ} \mathrm{C}$ and $90^{\circ} \mathrm{C}$ by impedance spectroscopy in the frequency range of $10<\mathrm{f}<10^{7} \mathrm{~Hz}$ applying a $0.1 \mathrm{~V}$ signal amplitude. A Novocontrol broadband dielectric Spectrometer (Hundsangen, Germany) integrated by an SR 830 lock-in amplifier with an Alpha dielectric interface was used. The membranes were previously equilibrated with deionized water (Milli-Q) and afterwards placed between two gold electrodes in a parallel plate liquid sample cell (BDS 1308, Novocontrol) coupled to the spectrometer. The hydration level of membranes differ between liquid- and vapour-equilibrated, e.g. $100 \%$ RH, environments [44-46]. For this reason and an approximation to the real DMFC conditions (aqueous solution in anode), the samples were soaked in Milli-Q water which was added to the measuring cell in each experiment. The temperature was controlled by nitrogen jet (QUATRO from Novocontrol) with a temperature error less than $0.1 \mathrm{~K}$ during every single sweep in frequency.

The protonic resistance $R(\Omega)$ was taken from the Bode plot as the value of the real part of the impedance $Z^{\prime}$ at which the phase angle reaches a maximum close to zero in the high frequency region, $\left|Z^{\prime}\right| \rightarrow R$. The real conductivity $\left(\sigma^{\prime}\right)$ of the membranes $\left(\mathrm{S} \mathrm{cm}^{-1}\right)$ was then calculated from the protonic resistance by means of Equation (6),

$\sigma^{\prime}=\frac{L}{R \cdot S}$

where $L$ is the thickness of the membrane $(\mathrm{cm})$ and $S$ the electrode area $\left(0.785 \mathrm{~cm}^{2}\right)$ in contact with the sample. 


\subsubsection{Direct Methanol Fuel Cell (DMFC) performance}

Membrane electrode assemblies (MEAs) comprising the nanocomposite membranes crosslinked at $110^{\circ} \mathrm{C}$ and $120^{\circ} \mathrm{C}$ were prepared for the evaluation of their DMFC performance with increasing temperatures. MEAs of a commercial Nafion ${ }^{\circledR} 115$ film (DuPont Co.) were also prepared for comparison.

Anode and cathode gas diffusion electrode layers were acquired from BalticFuelCells GmbH (Schwerin, Germany). The anode was composed of a carbon paper with microlayer (model H2315 T10A) from Freudenberg Group (Weinheim, Germany), which was coated to a $5.0 \mathrm{mg} \mathrm{cm}^{-2}$ catalyst loading with particles of an alloy of Pt-Ru black 50:50 (Alfa Aesar) incorporating a $20 \mathrm{wt} \%$ content of dry Nafion ${ }^{\circledR}$ ionomer. The cathode consisted of a carbon paper with microlayer from Freudenberg (model H2315 I3C4), which was coated to a $5.0 \mathrm{mg} \mathrm{cm}^{-2}$ loading with a catalyst made of platinum nanoparticles supported on advanced carbon (HiSPEC 13100, Alfa Aesar), ratio of $70 \mathrm{wt} \% \mathrm{Pt}$ on $\mathrm{C}$, containing $20 \mathrm{wt} \%$ of Nafion ${ }^{\circledR}$ ionomer.

The electrodes were cut in squares of $2.3 \mathrm{~cm}$ side length (about $5 \mathrm{~cm}^{2}$ area) and sandwiched between fully hydrated membranes. Finally, the MEAs were hot pressed at $110^{\circ} \mathrm{C}$ under a pressure of $300 \mathrm{~N} \mathrm{~cm}^{-2}$ for $3 \mathrm{~min}$. On the other hand, the MEAs of Nafion ${ }^{\circledR}$ membranes were obtained pressing at $135^{\circ} \mathrm{C}$ instead. In all cases, the prepared MEAs were stored in water until fuel cell experiments were performed.

For measuring DMFC performance, the MEAs were placed into a single fuel cell hardware (quick CONNECT, Baltic Fuel Cells GmbH, Germany) containing graphite plates with serpentine flow fields of $5 \mathrm{~cm}^{2}$ active area, and equipped with a pressurecontrolled clamping force system.

An aqueous methanol solution of $2 \mathrm{M}$ concentration was pumped at a flow rate of $6 \mathrm{ml} \mathrm{min} \mathrm{m}^{-1}$ to feed the anode. The cathode was fed with non-humidified oxygen gas at a flow rate of $250 \mathrm{ml} \mathrm{min}^{-1}$ and atmospheric pressure.

Polarization curves $(i-V)$ were obtained at several temperatures, i.e. $80{ }^{\circ} \mathrm{C}$, $100{ }^{\circ} \mathrm{C}$ and $120^{\circ} \mathrm{C}$, by stepwise increment of the current from open-circuit voltage conditions $(i \approx 0)$. Current and power density values were accordingly calculated and represented. Before $i$ - $V$ measurements, the MEAs were electrochemically activated for $5 \mathrm{~h}$ running current sweep cycles.

\section{Results and discussion}

\subsection{Electrospinning of SPEEK-30\%PVB nanofibers}

Electrospinning is a very suitable technique for the scalable fabrication of nanofibers via electrostatic phenomena induced by large electric fields between a needle and a collector [47]. Recently, a novel approach has been proposed in which nanofibers are produced by strong centrifugal forces (centrifugal spinning) enabling higher production rates [48].

Although electrospinning can be defined as a simple technique, the process is influenced by many parameters, i.e. surface tension of polymer solution, polymer concentration, viscosity, solvent volatility, conductivity, flow rate, needle-collector distance, applied potential, surrounding humidity, etc., which makes setting optimal electrospinning parameters rather complicated [47].

Effect of polymer concentration was analyzed for SPEEK-30\%PVB solutions in DMAc solvent under the following electrospinning conditions: The needle and the 
planar collector were separated $25 \mathrm{~cm}$ and energized to a potential of $+10 \mathrm{kV}$ and $-25 \mathrm{kV}$, respectively, pumping the polymer solution at a flow rate of $0.2 \mathrm{ml} \mathrm{h}^{-1}$ while electrospinning was carried below $40 \mathrm{RH} \%$. In Fig. 1 are shown the different electrospun nanofiber morphologies prepared from solutions between $12.5 \mathrm{wt} \%$ and $20 \mathrm{wt} \%$ polymer concentration.

At the lower polymer concentration range, i.e. $12.5 \mathrm{wt} \%$ and $15 \mathrm{wt} \%$, defects known as "beads" are visible thus indicating that solution viscosity was insufficient. On the other hand, at the higher concentration range, i.e. $17.5 \mathrm{wt} \%$ and $20 \mathrm{wt} \%$, perfect developed nanofibers are observed. The $20 \mathrm{wt} \%$ solution was found to be very viscous and it is empirically accepted that nanofiber diameter increases with increasing viscosity. Thereby, the solution with a total polymer concentration of $17.5 \mathrm{wt} \%$ was selected for the optimal preparation of SPEEK-30\%PVB nanofibers.

$<$ Figure 1>

The electrospun nanofiber mats, from a SPEEK-30\%PVB solution of $17.5 \mathrm{wt} \%$ concentration, were first heated at $160{ }^{\circ} \mathrm{C}$ for the removal of remaining DMAc solvent molecules and finally crosslinked at $200{ }^{\circ} \mathrm{C}$. Fig. 2 shows that the nanofiber morphology is preserved after the crosslinking process and the subsequent immersion in boiling water for $1 \mathrm{~h}$ despite densification and welding of the nanofibers are manifested. This confirms that the crosslinked nanofibers have a high chemical stability as required for withstanding hot aqueous environments of methanol solutions (DMFC operation above $\left.80^{\circ} \mathrm{C}\right)$.

$<$ Figure 2>

\subsection{Preparation of nanocomposite membranes. SEM analysis}

The method applied for the incorporation of the SPEEK-35\%PVA matrix between the nanofibers of SPEEK-30\%PVB has been analyzed studying superficial and transversal views of the prepared nanocomposite membranes.

The surface and cross-section of a sample of nanocomposite membrane is observed in Fig. 3. The surface is compact with no visible pores, and the cross-section reveals two regions: The outer layers of pure SPEEK-35\%PVA phase show a perfect fragile rupture and the inner layer contains evidence of a more plastic rupture, which is assigned to the presence of the nanofiber mat within the SPEEK-35\%PVA matrix and the formation of a strong fiber-matrix interface.

These observations confirm that a good penetration of the aqueous SPEEK$35 \%$ PVA solution into the nanofiber mats occurs, which leads to the successful impregnation and loading of the matrix phase along the whole nanofiber layer thus forming a perfect sandwich structure.

$<$ Figure 3>

\subsection{Water uptake, swelling degree and ion-exchange capacity}

The ion-exchange capacity represents the density of sulfonic acid groups present in the material. The high acid strength of the sulfonic moiety causes water to be incorporated into the ionic channels via hydrated protons $\left(\mathrm{H}_{3} \mathrm{O}^{+}\right)$strongly hydrogen-bonded to water molecules [49], which is represented by the water uptake, and the volume occupied by 
such an amount of water is measured through the swelling degree. Proton conductivity and methanol permeability are associated with IEC, water uptake and swelling degree; both generally increasing with those parameters [50-53]. However, if water uptake and swelling degree surpass some critical value, it has been noticed that proton conductivity can be prone to diminish as a consequence of a dilution effect which decreases the local concentration of protons within the ionic channels [54].

Table 1 lists the swelling degree, water uptake and IEC parameters of the nanocomposite membranes as a function of crosslinking temperature. Membranes prepared without nanofibers, i.e. SPEEK-35\%PVA, have also been characterized for comparison.

Table 1. Swelling (in-plane and through-thickness), water uptake and ion-exchange capacity (IEC) values of the SPEEK-35\%PVA and nanocomposite membranes are reported as a function of crosslinking temperature after $1 \mathrm{~h}$ in boiling water. Membrane thickness is given in dry state as a reference.

\begin{tabular}{ccccccc}
\hline Membrane & $\begin{array}{c}\text { Cross. } \\
\text { temp. } \\
(\mathbf{0} \mathbf{C})\end{array}$ & $\begin{array}{c}\text { Dry } \\
\text { thickness } \\
(\boldsymbol{\mu m})\end{array}$ & $\begin{array}{c}\text { In-plane } \\
\text { Swelling } \\
(\boldsymbol{\%})\end{array}$ & $\begin{array}{c}\text { Thickness } \\
\text { swelling } \\
(\boldsymbol{\%})\end{array}$ & $\begin{array}{c}\text { Water } \\
\text { uptake } \\
(\boldsymbol{\%})\end{array}$ & $\begin{array}{c}\text { IEC } \\
\left(\mathbf{m e q ~}^{\mathbf{- 1}}\right)\end{array}$ \\
\hline SPEEK-35\%PVA & 110 & $92 \pm 3$ & $203 \pm 7$ & $50 \pm 5$ & $283 \pm 12$ & $0.22 \pm 0.01$ \\
\hline Nanocomposite & 110 & $70 \pm 5$ & $59 \pm 5$ & $109 \pm 12$ & $192 \pm 12$ & $0.22 \pm 0.01$ \\
\hline SPEEK-35\%PVA & 120 & $89 \pm 3$ & $107 \pm 6$ & $37 \pm 4$ & $152 \pm 7$ & $0.47 \pm 0.01$ \\
\hline Nanocomposite & 120 & $72 \pm 5$ & $44 \pm 5$ & $42 \pm 6$ & $86 \pm 9$ & $0.31 \pm 0.01$ \\
\hline SPEEK-35\%PVA & 130 & $86 \pm 3$ & $44 \pm 5$ & $26 \pm 3$ & $67 \pm 4$ & $0.50 \pm 0.01$ \\
\hline Nanocomposite & 130 & $69 \pm 6$ & $21 \pm 4$ & $25 \pm 4$ & $42 \pm 5$ & $0.27 \pm 0.01$ \\
\hline SPEEK-35\%PVA & 140 & $83 \pm 3$ & $21 \pm 4$ & $19 \pm 2$ & $36 \pm 3$ & $0.25 \pm 0.01$ \\
\hline Nanocomposite & 140 & $66 \pm 5$ & $17 \pm 4$ & $21 \pm 3$ & $34 \pm 5$ & $0.56 \pm 0.01$ \\
\hline
\end{tabular}

It can be deduced from Table 1 that in-plane swelling, through-thickness swelling and water uptake in both type of membranes diminish with increasing temperature of crosslinking. The nanocomposite membranes remarkably show larger dimensional changes through-thickness than in-plane, which is inferred to the 2-D (plane) mechanical reinforcing effect provided by the nanofibers. This is especially observed with the nanocomposite membranes crosslinked at $110^{\circ} \mathrm{C}$ and $120^{\circ} \mathrm{C}$; conditions in which the SPEEK-35\%PVA matrix is just partially crosslinked as deduced from the high water uptake values. Constraint of the swelling as a consequence of the reinforcement with nanofibers is clearly demonstrated by comparison of the water uptake values between SPEEK-35\%PVA and nanocomposite membranes crosslinked at those temperatures. This suggests the nanocomposite membranes to be mechanically more stable under typical cyclic hydration conditions occurring due to fuel cell operation. Such a cyclic swelling/water uptake of the membrane is prone to generate mechanical stresses and fatigue, thus influencing the long-term operational lifetime [55].

On the other hand, the differences of the swelling and water uptake parameters between both type of membranes diminish with increasing crosslinking temperature and converge at $140^{\circ} \mathrm{C}$. This result points out that the crosslinking degree approaches a maximum level towards a temperature of about $140{ }^{\circ} \mathrm{C}$. Consequently, a higher crosslinking degree of the matrix must come accompanied by an important improvement of its mechanical properties, thus decreasing the reinforcement benefit associated with the nanofibers. 
Interestingly, the SPEEK-35\%PVA membranes prepared in this study by casting from an aqueous solution can be crosslinked at much lower temperatures than those cast with DMAc solvent such us in our previous work [42]. Likely, the strong polar nature and hydrogen-bonding capacity of water favor the orientation of the sulfonic acid groups $\left(-\mathrm{SO}_{3} \mathrm{H}\right)$ of SPEEK against the hydroxide groups $(-\mathrm{OH})$ of PVA, then facilitating the corresponding acid-base reaction.

The ion-exchange capacities measured for the membranes in Table 1 do not represent a meaningful result. The authors suggest that salt rejection, $\mathrm{NaCl}$ in this case, might be occurring and, therefore, ion-exchange of protons by sodium ions $\left(\mathrm{Na}^{+}\right)$not taking place. Indeed, some literature reports the salt rejection properties of SPEEKcontaining membranes due to the fixed negative charges of the dissociated sulfonic groups which repel anions such us sulfate and chloride [56-58]. An important application for this kind of membranes involves nanofiltration for water purification. Furthermore, salt rejection might be encouraged in our composition by the presence of PVA [59]. It can be then concluded that other salt compositions should be investigated to minimize salt rejection and allow the correct measurement of IEC on this type of membranes. Similarly, this particular phenomenon might take place in other sulfonated hydrocarbon materials different to SPEEK.

\subsection{FTIR results}

Analysis of the crosslinking reactions between SPEEK-PVA and SPEEK-PVB chains mixed in DMAc solvent was conducted by means of the FTIR and DSC techniques and reported by the authors [42]. Those reactions were mainly assigned to the condensation between sulfonic acids of SPEEK and OH groups of PVA and PVB, and in some extent to reactions between the sulfonic acid groups and intermediate species derived from the thermal degradation of PVA and PVB. In this work, the crosslinking reaction between the SPEEK and PVA polymers blended in water solvent was evaluated preparing samples of SPEEK-35\%PVA membranes by casting their aqueous solutions. Samples with similar thickness were obtained and the FTIR spectra associated with such membranes are represented in Fig. 4.

The profiles of the blended SPEEK-PVA membranes predominantly exhibit the characteristic peaks of SPEEK, which can be understood as SPEEK is the principal constituent material of the membranes. Accordingly, the following peaks can be distinguished: $\mathrm{O}-\mathrm{H}$ species from sulfonic acid groups vibrate at about $3450 \mathrm{~cm}^{-1}$, while other bands assigned to sulfonic acid are found at $1247 \mathrm{~cm}^{-1}, 1079 \mathrm{~cm}^{-1}$ and $1025 \mathrm{~cm}^{-1}$. A peak at $1652 \mathrm{~cm}^{-1}$ corresponds to the carbonyl group of the SPEEK structure, and the peaks at $1491 \mathrm{~cm}^{-1}$ and $1221 \mathrm{~cm}^{-1}$ evidence the presence of $\mathrm{C}-\mathrm{C}$ aromatic ring and aromatic C-O-C bonds, respectively $[60,61]$.

It is reported that PVA typically shows a broad peak ranging from $3700 \mathrm{~cm}^{-1}$ to $3000 \mathrm{~cm}^{-1}$ and centered around $3300 \mathrm{~cm}^{-1}$, which is attributed to stretching of the hydroxyl $(\mathrm{O}-\mathrm{H})$ groups $[60,62]$. Consequently, the bands of the vibrating $\mathrm{O}-\mathrm{H}$ bonds belonging to the sulfonic acid groups of SPEEK and the hydroxide groups of PVA overlap. This should explain the large peaks observed in Fig. 4 at those wavenumbers. The largest peak appears on the as-prepared sample which has not been crosslinked, and it progressively decreases after crosslinking at $120^{\circ} \mathrm{C}$ and $140{ }^{\circ} \mathrm{C}$. The condensation reaction between sulfonic acids and hydroxyl groups explains the consumption of $\mathrm{OH}$ moieties with the corresponding decrease of the associated peak [42]. This corroborates that crosslinking reactions take place between $110^{\circ} \mathrm{C}$ and $140{ }^{\circ} \mathrm{C}$ in SPEEK-35\%PVA compositions prepared from aqueous solutions, in contrast to the SPEEK-PVA 
formulations mixed in DMAc solvent in which crosslinking was only achieved at about $200{ }^{\circ} \mathrm{C}[42]$.

$<$ Figure 4>

\subsection{Mechanical properties}

Static mechanical testing has been carried out on samples of SPEEK-35\%PVA and nanocomposite membranes crosslinked at $120^{\circ} \mathrm{C}$. The purpose is to compare their mechanical properties and evaluate the effect of the nanofibers. It is of special interest to corroborate that the preparation method leads to compact nanocomposite membranes with negligible defects.

Mechanical parameters such us Young's modulus, ultimate tensile strength and tensile rupture strain were obtained and are reported in Table 2. Statistically, no significant differences are found between both membranes and no apparent influence of the nanofibers demonstrated. A plausible explanation can be given taking into account that the previously hydrated membranes were partially dried before the tests by placing them between two plastic sheets under pressure and at $35^{\circ} \mathrm{C}$ for 4 days. At those conditions, the mechanical properties of the matrix and nanofibers seem to coincide. On the other hand, for fully hydrated conditions, the mechanical strength of the swollen matrix will weaken as a function of water uptake and the reinforcing effect of the nonswollen nanofibers would be expected to become evident. Unfortunately, our setup did not allow the samples to be maintained at a fully hydrated state. When hydrated samples were tested, they were losing water during the measurements in air and no reliable data was obtained. Consequently, it was decided to measure samples with lower water content. According to their similar results observed in Table 2, it can be confirmed the successful introduction of the matrix phase between the nanofibers of the mats without any evidence of weakening defects such us pores.

An observed advantage of introducing nanofibers arises from the induced mechanical stability of the membranes. It was noted that the SPEEK-based membranes tend to be brittle when their water content decreases up to a dry state as they shrink. However, the nanocomposite membranes were less affected by such a shrinking process and their physical integrity was preserved to a greater extent.

Table 2. Average values of Young's modulus $(E)$, ultimate tensile strength $\left(\sigma_{u l t}\right)$ and tensile rupture strain $\left(\varepsilon_{r}\right)$ for samples crosslinked at $120^{\circ} \mathrm{C}$ of SPEEK-35\%PVA and nanocomposite membranes.

\begin{tabular}{cccc}
\hline Sample & $\mathbf{E}(\mathbf{G P a})$ & $\boldsymbol{\sigma}_{\text {ult }}(\mathbf{M P a})$ & $\boldsymbol{\varepsilon}_{\mathbf{r}}(\boldsymbol{\%})$ \\
\hline SPEEK-35\%PVA & $1.3 \pm 0.3$ & $48 \pm 8$ & $21 \pm 7$ \\
\hline Nanocomposite & $1.2 \pm 0.4$ & $47 \pm 7$ & $16 \pm 5$ \\
\hline
\end{tabular}

\subsection{Methanol permeability}

The reduction and limitation of methanol permeability through a membrane is an essential matter for the practical application of Direct Methanol Fuel Cells. Fuel loss and decrease of electrochemical efficiency at the cathode are the main issues to avoid.

Methanol permeability has been measured at $60^{\circ} \mathrm{C}$ by analyzing the change of methanol concentration in the receptor chamber $\left(C_{R}\right)$ as a function of time $(t)$ during the pseudo-steady state conditions. Linear trends with R-squared fitted lines are obtained and slopes, expressed by $C_{R} / t$, estimated. The values of the slopes are introduced in Equation (5) and then the apparent methanol permeabilities are calculated from the 
membrane thickness and other experimental parameters. The methanol permeability is described as 'apparent' due to the fact that includes the effect of the boundary layers in addition to the permeation across the membrane itself.

Figure 5 plots the profiles of methanol concentration versus elapsed time for the nanocomposite membranes crosslinked at $110^{\circ} \mathrm{C}, 120^{\circ} \mathrm{C}, 130{ }^{\circ} \mathrm{C}$ and $140{ }^{\circ} \mathrm{C}$, which presented a thickness after experiments of $145 \mu \mathrm{m}, 107 \mu \mathrm{m}, 88 \mu \mathrm{m}$ and $71 \mu \mathrm{m}$, respectively. In Table 3 are recorded the values of apparent methanol permeability for all the SPEEK-35\%PVA and nanocomposite membranes prepared in this study, which are represented in Figure 6 as a function of crosslinking temperature.

Methanol permeability is clearly related with the water uptake values of the membranes given in Table 1 . Water uptake was particularly constrained by the presence of SPEEK-30\%PVB nanofibers when the SPEEK-35\%PVA matrix was crosslinked at $110^{\circ} \mathrm{C}$ and $120^{\circ} \mathrm{C}$, following this order. Figure 6 corroborates this fact in terms of methanol permeability, and it shows that the nanocomposite membranes crosslinked at $110{ }^{\circ} \mathrm{C}$ and $120^{\circ} \mathrm{C}$ decreased the methanol crossover in comparison with the SPEEK$35 \%$ PVA membranes crosslinked at the similar temperatures. Specifically, the latter exhibited relatively high methanol permeabilities when $\mathrm{Nafion}^{\circledR}$ is considered as a reference material.

Interestingly, the nanocomposite membrane which was crosslinked at $120^{\circ} \mathrm{C}$ had a methanol permeability equivalent to Nafion ${ }^{\circledR}$, while those membranes crosslinked at $130{ }^{\circ} \mathrm{C}$ and $140{ }^{\circ} \mathrm{C}$ much lower values. Methanol permeability reduced with increasing temperature of crosslinking but no significant differences are observed between SPEEK-35\%PVA and nanocomposite membranes crosslinked at $130{ }^{\circ} \mathrm{C}$ and $140{ }^{\circ} \mathrm{C}$. This is inferred to the higher crosslinking degrees reached at those temperatures which causes no valuable effect of the nanofibers on the crosslinked matrix.

\section{$<$ Figure 5> and <Figure 6>}

Table 3. Values at $60^{\circ} \mathrm{C}$ of apparent methanol permeability $(P)$ and proton conductivity $\left(\sigma^{\prime}\right)$ for the SPEEK-35\%PVA and nanocomposite membranes as a function of crosslinking temperature. A modified characteristic factor is calculated as $\Phi=\sigma^{2} / P$ for theoretical evaluation of materials performance in DMFC operating conditions. A Nafion ${ }^{\circledR} 115$ membrane is included for reference.

\begin{tabular}{|c|c|c|c|c|}
\hline Membrane & $\begin{array}{c}\text { Crosslinking } \\
\text { temperature } \\
\left({ }^{\circ} \mathrm{C}\right) \\
\end{array}$ & $\begin{array}{c}\text { Methanol } \\
\text { permeability } \\
\left(\mathrm{cm}^{2} \mathrm{~s}^{-1}\right)\end{array}$ & $\begin{array}{c}\text { Proton } \\
\text { conductivity } \\
\left(\mathrm{S} \mathrm{cm}^{-1}\right)\end{array}$ & $\begin{array}{c}\text { Modified } \\
\text { characteristic factor } \\
\left(\mathrm{S}^{2} \mathrm{~s} \mathrm{~cm}^{-4}\right)\end{array}$ \\
\hline SPEEK-35\%PVA & 110 & $(5.81 \pm 0.20) \cdot 10^{-6}$ & $(1.11 \pm 0.08) \cdot 10^{-2}$ & $21.2 \pm 3.2$ \\
\hline Nanocomposite & 110 & $(4.43 \pm 0.21) \cdot 10^{-6}$ & $(1.35 \pm 0.11) \cdot 10^{-2}$ & $41.1 \pm 5.8$ \\
\hline SPEEK-35\%PVA & 120 & $(4.70 \pm 0.13) \cdot 10^{-6}$ & $(1.10 \pm 0.05) \cdot 10^{-2}$ & $25.7 \pm 1.9$ \\
\hline Nanocomposite & 120 & $(3.82 \pm 0.18) \cdot 10^{-6}$ & $(1.03 \pm 0.08) \cdot 10^{-2}$ & $27.8 \pm 3.6$ \\
\hline SPEEK-35\%PVA & 130 & $(2.18 \pm 0.07) \cdot 10^{-6}$ & $(5.84 \pm 0.32) \cdot 10^{-3}$ & $15.6 \pm 1.5$ \\
\hline Nanocomposite & 130 & $(2.02 \pm 0.11) \cdot 10^{-6}$ & $(2.50 \pm 0.18) \cdot 10^{-3}$ & $3.1 \pm 0.3$ \\
\hline SPEEK-35\%PVA & 140 & $(1.19 \pm 0.06) \cdot 10^{-6}$ & $(3.53 \pm 0.13) \cdot 10^{-3}$ & $10.5 \pm 0.3$ \\
\hline Nanocomposite & 140 & $(1.34 \pm 0.09) \cdot 10^{-6}$ & $(1.63 \pm 0.10) \cdot 10^{-3}$ & $2.0 \pm 0.1$ \\
\hline Nafion $^{\circledR} 115$ & - & $(3.71 \pm 0.05) \cdot 10^{-6}$ & $(3.64 \pm 0.11) \cdot 10^{-2}$ & $357 \pm 24$ \\
\hline
\end{tabular}

\subsection{Proton conductivity}

The proton conducting properties of the SPEEK-30\%PVB nanofibers and the prepared membranes were examined from impedance measurements at $60{ }^{\circ} \mathrm{C}$ and $90^{\circ} \mathrm{C}$. Bode 
diagrams were analyzed by plotting the real part of the conductivity versus frequency. The proton conductivity was obtained at the region of high frequencies in which the real conductivity tends to a plateau when the phase angle value approaches zero.

The Bode diagram of a SPEEK-30\%PVB nanofiber mat in Fig. 7 shows the profile of real conductivity versus frequency obtained at $90{ }^{\circ} \mathrm{C}$. The mat, which previously was placed $1 \mathrm{~h}$ in boiling water, was washed with deionized Milli-Q water and the thickness measured $(283 \mu \mathrm{m})$. Milli-Q water was introduced in the conductivity cell in order to ensure a fully hydrated state of the mat during measurements. For comparison, a SPEEK-30\%PVB membrane was prepared by casting from a DMAc solution and similar conductivity measurements performed. The membrane was previously swollen in boiling water for $1 \mathrm{~h}(260 \mu \mathrm{m}$ thick) and Milli-Q water was also added to the conductivity cell. The result of this membrane at $90{ }^{\circ} \mathrm{C}$ is included in Fig. 7 and displays a conductivity $\left(6.11 \cdot 10^{-4} \mathrm{~S} \mathrm{~cm}^{-1}\right)$ about $1 / 43$ the conductivity value of the nanofiber mat $\left(2.61 \cdot 10^{-2} \mathrm{~S} \mathrm{~cm}^{-1}\right)$. This confirms that the SPEEK-30\%PVB nanofibers are good proton-conducting materials. Furthermore, the different phase angle profiles found in Fig. 7 between the nanofiber mat and the SPEEK-30\%PVB membrane corroborate that proton conduction takes place along distinct pathways. Two proton conduction mechanisms associated to the nanofiber morphology could explain this large increment of proton conductivity. On one side, conductivity may be improved through the bulk due to an induced preferential orientation of the ionic channels along the nanofiber axis, and on the other side, conductivity may be encouraged on the nanofiber surface through the strong interface formed between water molecules and external sulfonic acid groups [32].

The values of proton conductivity of the SPEEK-35\%PVA and nanocomposite membranes obtained at $60{ }^{\circ} \mathrm{C}$ are given in Table 3. Comparison between both types of membranes at each crosslinking temperature reveals the influence of the SPEEK$30 \%$ PVB nanofibers on the conductivity. Clearly, when the nanocomposite membrane has been crosslinked at $110{ }^{\circ} \mathrm{C}$ and water uptake reaches a very high level (see Table 1), the proton conductivity of the nanocomposite membrane exceeds the conductivity of the SPEEK-35\%PVA matrix. This confirms a positive contribution of the nanofibers on the conductivity. Crosslinking at $120^{\circ} \mathrm{C}$ has almost no effect on the SPEEK-35\%PVA membrane despite the lower water uptake (Table 1), but decreases the conductivity of the nanocomposite membrane until a value close to the pristine SPEEK-35\%PVA phase. Further increase of the crosslinking temperature to $130{ }^{\circ} \mathrm{C}$ and $140{ }^{\circ} \mathrm{C}$ results on proton conductivities of the nanocomposite membranes significantly below the conductivities found in the SPEEK-35\%PVA membranes. Although the water uptake values at those crosslinking conditions are rather similar between both types of membranes (Table 1), the presence of nanofibers has a negative repercussion. Likely, SPEEK from the nanofibers reacts with PVA from the matrix and the formed interface restricts the presence of water on the nanofiber surface for proton conduction, and in addition, sulfonic acid groups for the donation of protons are consumed. These phenomena could even make the nanofibers to block proton transport through the matrix. Then, apparently, reduction of surface concentration of water molecules and sulfonic acid groups on the SPEEK-30\%PVB nanofibers strongly affects their conductivity properties as a consequence of a more limited proton conduction via the water-sulfonic acid association. This conclusion about conductivity preferentially taking place on the nanofibers surface would be in agreement with those reported in other studies [32,63]. Moreover, this explanation can be supported by the fact that nanofiber axis orientation is perpendicular to the proton conduction direction, which might difficult conductivity through the nanofiber bulk but on the nanofiber surface. 
Table 3 also compiles the values of a modified characteristic factor which is a theoretical consideration for the suitable estimation of DMFC performance of polymer electrolytes under practical operating conditions. Typically, the characteristic factor is conceived as $\Phi=\sigma^{\prime} / P$, thus suggesting that both proton conductivity and methanol permeability equally influence DMFC performance. Consequently, a simultaneous and equivalent increment of proton conductivity and methanol permeability would not cause any change on the DMFC performance. However, many authors have empirically demonstrated that proton conductivity is the main parameter governing the DMFC performance during standard operating conditions [33-35]. This is explained by the fact that methanol is electrochemically oxidized at the anode and, thereby, the driving force for methanol permeation, that is the concentration gradient, diminishes with increasing current density. Thus, reaching certain levels of current density makes their associated ohmic losses prevail upon the methanol crossover effect to explain the electrochemical performance. This reason makes us to propose a modified characteristic factor in which proton conductivity is emphasized against methanol permeability without completely neglecting its negative effect. The modified characteristic factor is correspondingly defined as $\Phi=\sigma^{\prime 2} / P[42]$.

Nafion ${ }^{\circledR}$ is an outstanding polymer electrolyte membrane although its main drawback comes from the extremely high cost of this perfluorinated material. We can observe in Table 3 that it is the best performing material according to its modified characteristic factor. Nevertheless, the purpose of this study is replacing Nafion ${ }^{\circledR}$ with more cost effective SPEEK-based materials.

Attending to the modified characteristic factors calculated for the prepared SPEEK-containing membranes in Table 3, the nanocomposite membranes crosslinked at $110^{\circ} \mathrm{C}$ and $120^{\circ} \mathrm{C}$ show a priori the best properties for the achievement of optimal DMFC performances. In this case, it is worth mentioning that the nanocomposite membrane crosslinked at $120^{\circ} \mathrm{C}$ is superior to the former from a mechanical stability point of view.

Figure 8 encompasses the proton conductivities of the SPEEK-35\%PVA and nanocomposite membranes measured at $90{ }^{\circ} \mathrm{C}$. The conductivity of the nanocomposite membrane crosslinked at $110^{\circ} \mathrm{C}\left(1.64 \cdot 10^{-2} \mathrm{~S} \mathrm{~cm}^{-1}\right)$ surpasses the conductivity exhibited by the SPEEK-35\%PVA membrane crosslinked at the same temperature $\left(1.03 \cdot 10^{-2} \mathrm{~S} \mathrm{~cm}^{-1}\right)$. The conductivity of the nanocomposite membrane crosslinked at $120{ }^{\circ} \mathrm{C}\left(1.16 \cdot 10^{-2} \mathrm{~S} \mathrm{~cm}^{-1}\right)$ decreases in comparison with that one crosslinked at $110{ }^{\circ} \mathrm{C}$ and it is also below the conductivity of the SPEEK-35\%PVA membrane crosslinked at $120{ }^{\circ} \mathrm{C}\left(1.80 \cdot 10^{-2} \mathrm{~S} \mathrm{~cm}^{-1}\right)$. A similar trend is distinguished from the results at $60{ }^{\circ} \mathrm{C}$ in Table 3. On the other hand, the SPEEK-35\%PVA membranes crosslinked at $110^{\circ} \mathrm{C}$ and $120^{\circ} \mathrm{C}$ reveal a particular behaviour. The proton conductivities of such membranes are practically similar at $60{ }^{\circ} \mathrm{C}$ (Table 3), but the SPEEK-35\%PVA membrane crosslinked at $120^{\circ} \mathrm{C}$ shows a higher conductivity at $90{ }^{\circ} \mathrm{C}$ than the membrane crosslinked at $110{ }^{\circ} \mathrm{C}$ (Fig. 8). Since swelling and water uptake increase with increasing temperature, especially above a critical temperature which depends on the IEC, it is inferred that the lower crosslinking degree reached at $110^{\circ} \mathrm{C}$ will promote a larger water uptake during the measurement at $90^{\circ} \mathrm{C}$ than at $60^{\circ} \mathrm{C}$. Correspondingly, the larger fraction of water confined within the membrane will cause a diluting effect of the sulfonic acid groups thus decreasing the conductivity [54]. Crosslinking at $120^{\circ} \mathrm{C}$ seems to be optimal for the control of excessive water uptake while still not considerably reducing this parameter for the final achievement of a good proton conduction.

It is then plausible to affirm that proton conductivity of the nanocomposite membranes depends on the nanofiber mats via the conductivity contribution of those 
nanofibers and their capacity to control swelling and water uptake of the matrix. Membranes with low crosslinking levels are then the most favoured by the nanofibers.

$<$ Figure $7>$ and $<$ Figure $8>$

\subsection{DMFC performance}

The response of the nanocomposite membranes crosslinked at $110^{\circ} \mathrm{C}$ and $120^{\circ} \mathrm{C}$ under DMFC operation is shown in Figure 9. A standard Nafion ${ }^{\circledR}$ membrane (N115) is included as a reference. Electrochemical performance was evaluated from $80^{\circ} \mathrm{C}$ to $120{ }^{\circ} \mathrm{C}$ at atmospheric pressure with the anode and cathode fed by a $2 \mathrm{M}$ aqueous methanol solution and pure oxygen (without humidification), respectively.

The results at $120^{\circ} \mathrm{C}$ operation have been modeled using Equation (7), in which mass transport limitation phenomena are not considered for simplification.

$V=V_{O C}-A_{1} \cdot \ln \frac{i}{i_{0}}-R_{M E A} \cdot i \cdot S$

The parameter $V$ represents the cell voltage, $V_{O C}$ the reversible open-circuit voltage, $A_{1}$ the sum of the Tafel slopes for anode and cathode, $i$ the cell current density (defined as I/S), $i_{0}$ the exchange current density (catalytic function), $R_{M E A}$ the ohmic resistance of the MEA (mainly caused by the ionic resistance of the membrane), $S$ the geometrical area of the membrane and $I$ the total cell current.

Attempts to estimate the electro-osmotic methanol crossover during DMFC experiments involve the mathematical model given in Equation $(8)[38,64]$, valid for an equivalent geometrical area of the membrane $(S)$ of $1 \mathrm{~cm}^{2}$,

$V\left(i, C_{a n}\right)=V_{O C}-A_{1} \cdot \ln \left(\frac{i}{i_{0}}\right)-A_{2} \cdot C_{a n}-A_{3} \cdot i$

with,

$A_{3}=\frac{L}{\sigma}+A_{\text {eos }}$

where $A_{2}$ represents the overvoltage caused by diffusion of methanol under a concentration gradient (no current dependent), $C_{a n}$ is the methanol concentration at the anode and $A_{3}$ represents the overvoltage due to the sum of the protonic resistance and the methanol electro-osmotic effect as both depend on current density. From Equation (9), it is detailed that $A_{3}$ depends on $L$ and $\sigma$, which are the thickness and conductivity of the membrane, respectively, and a term $A_{\text {eos }}$ associated with the electroosmosis of methanol.

The derivative $d V / d i$ when a constant concentration of methanol in the anode is assumed, is equal to,

$\frac{d V}{d i}=-\frac{A_{1}}{i}-A_{3}$

Plotting $d V / d i$, preferably between $100-350 \mathrm{~mA} \mathrm{~cm}^{-2}$, the slope gives the value of $A_{3}$ as seen in Equation (10). Then, $A_{e o s}$ can be calculated introducing in Equation (9) 
those values of $L$ and $\sigma$ previously measured experimentally. Although this is a good approach to evaluate the electro-osmotic effect taking place in a membrane, there is a point which weakens this model. In our new consideration, the drawback comes from the fact that proton conductivity can be influenced by methanol crossover. It has been established that an alcohol environment, e.g. methanol, can affect the dissociation of the sulfonic acid groups thus reducing the proton conductivity [65]. This is explained by the lower relative dielectric constant of methanol $\left(33.1\right.$ at $20^{\circ} \mathrm{C}$ ) in comparison with water $\left(80.4\right.$ at $20^{\circ} \mathrm{C}$ ). Therefore, the proton conductivity cannot be considered to be a constant independent of methanol crossover and, consequently, this model description becomes strictly not true. Indeed, a new parameter $A_{3}{ }^{*}$ should be defined to express the change of membrane resistivity due to the modified proton conductivity of the membrane as a consequence of the mixture of water and methanol within the ionic channels. In this case, $A_{2}$ will include the effect of methanol permeation by diffusion on both the membrane conductivity and catalyst performance, while the new $A_{3}{ }^{*}$ parameter in Equation (11) will consider the effect of electro-osmosis of methanol on the conductivity.

$\frac{d V}{d i}=-\frac{A_{1}}{i}-A_{3}-\frac{d A_{3}}{d i} \cdot i=-\frac{A_{1}}{i}-A_{3}-A_{3}^{*} \cdot i$

It is speculated that the methanol barrier layer should concentrate near the anode side in an asymmetric membrane configuration. Consequently, it would be minimized the accumulation of methanol within the membrane which in turn would decrease the proton conductivity. Following this line, it is predicted the worst situation to occur if the methanol barrier layer would face the cathode site. The nanocomposite membranes of this study contain the nanofiber-based methanol barrier layer in a symmetric centered position (sandwich structure). Next steps should then address the preparation of asymmetric nanofiber-reinforced membranes and their DMFC performance evaluation as a function of methanol barrier layer position.

Fitting of Equation (7) to the experimental $i$ - $V$ values was carried out through the minimum mean square error method, $\Sigma\left(V_{\text {exp }}-V_{\text {mod }}\right)^{2}$, in order to estimate the model parameters. Consequently, every given current density $(i)$ value was associated with an experimentally measured cell voltage $\left(V_{\text {exp }}\right)$ and a calculated value from the model $\left(V_{\text {mod }}\right)$. Power density $(P)$ curves were obtained via Equation (12),

$P=V \cdot i$

and therefore, two curves were figured, i.e. $P_{\text {exp }}=V_{\text {exp }} \cdot i$ and $P_{\text {mod }}=V_{\text {mod }} \cdot i$. Since power density is very sensitive to the cell voltage $\left(V^{2}\right)$ and a function of the ohmic resistance $\left(R_{M E A}\right)$, see Equation (13), this property has been used for a refined determination of the model parameters and especially the ohmic resistance term [66]. In our case, we conceived a global mean square error factor composed of $\Sigma\left(V_{\text {exp }}-V_{\text {mod }}\right)^{2} \cdot \Sigma\left(P_{\text {exp }}-P_{\text {mod }}\right)^{2}$ which was minimized by iterative calculations using a commercial computer software package. The respective calculated model parameters are reported in Table 4.

$P=\frac{V^{2}}{R_{M E A} \cdot S}$ 
Turning back to Fig. 9, we can observe that the nanocomposite membrane crosslinked at $120^{\circ} \mathrm{C}$ performed better than the nanocomposite membrane crosslinked at $110^{\circ} \mathrm{C}$. The former reaches a maximum DMFC performance of $81.2 \mathrm{~mW} \mathrm{~cm}^{-2}$ (at $280 \mathrm{~mA} \mathrm{~cm}^{-2}$ ) and the latter $67.1 \mathrm{~mW} \mathrm{~cm}^{-2}$ (at $260 \mathrm{~mA} \mathrm{~cm}^{-2}$ ) under an operating cell temperature of $80^{\circ} \mathrm{C}$. The performance increases to $96.0 \mathrm{~mW} \mathrm{~cm}^{-2}$ (at $400 \mathrm{~mA} \mathrm{~cm}^{-2}$ ) and $81.6 \mathrm{~mW} \mathrm{~cm}^{-2}$ (at $340 \mathrm{~mA} \mathrm{~cm}^{-2}$ ), respectively, when the cell temperature is $120^{\circ} \mathrm{C}_{\text {. }}$ Under similar operating conditions, i.e. at cell temperatures of $80^{\circ} \mathrm{C}$ and $120^{\circ} \mathrm{C}$, the Nafion ${ }^{\circledR}$ membrane achieved $87.1 \mathrm{~mW} \mathrm{~cm}^{-2}$ (at $280 \mathrm{~mA} \mathrm{~cm}^{-2}$ ) and $134.6 \mathrm{~mW} \mathrm{~cm}^{-2}$ (at $440 \mathrm{~mA} \mathrm{~cm}^{-2}$ ).

It can be visually distinguished in Figure 9 that activation polarization losses, observed by the potential drop at the beginning of the $i$ - $V$ profile, are relatively larger on the nanocomposite membrane crosslinked at $120^{\circ} \mathrm{C}$. The electrochemical performance of the electrodes decreases with increasing $A_{1}$ and decreasing $i_{0}$. Clearly, this is corroborated with the values of those parameters given in Table 4 for such a nanocomposite membrane. The reason of this poorer electrochemical performance associated with the catalyst activation remains unclear, although it is assumed that optimization of the MEA preparation still needs to be achieved.

Figure 10 compares the experimental and modeled profiles for the DMFC performance at $120^{\circ} \mathrm{C}$ of the nanocomposite and Nafion ${ }^{\circledR}$ membranes. A very good fitting is confirmed which validates the values given in Table 4 for the Equation (7) model parameters. Nevertheless, the last part of the curves at the highest current densities shows that the experimental profiles tend to be located below those modeled. This is attributed to the appearance of mass transport limitation effects at those conditions, and therefore, it especially occurs in the case of the nanocomposite membrane crosslinked at $120^{\circ} \mathrm{C}$ and Nafion ${ }^{\circledR}$ as both can reach higher currents.

Table 4 also includes the values of Open Circuit Potential $\left(V_{O C}\right)$, which are associated with the fuel crossover due to the voltage reduction caused by methanol on the oxygen reduction reaction at the cathode, for the membranes at $120{ }^{\circ} \mathrm{C}$ and a $2 \mathrm{M}$ aqueous methanol solution. In agreement with Fig. 6 and Table 3, the lower $V_{O C}$ value of the nanocomposite membrane crosslinked at $110^{\circ} \mathrm{C}$ confirms its higher methanol permeability characteristics. However, the nanocomposite membrane crosslinked at $120{ }^{\circ} \mathrm{C}$ reveals the largest $V_{O C}$ voltage despite its lower thickness in comparison with the Nafion ${ }^{\circledR}$ membrane. This suggests that although the permeability coefficient at $60{ }^{\circ} \mathrm{C}$ of this nanocomposite membrane was slightly superior to that of Nafion ${ }^{\circledR}$, the latter seems to increase further its methanol permeability at $120^{\circ} \mathrm{C}$ in relation to the nanocomposite membrane. This might be due to the reaching of the glass transition temperature of Nafion ${ }^{\circledR}$, ranged between $80-100^{\circ} \mathrm{C}$ under a fully hydrated state [41,67], which would explain an encouragement of its methanol transport properties.

Assuming that the ohmic resistance of a MEA is mainly the ionic resistance of the membrane, the calculated values of $R_{M E A}$ at $120^{\circ} \mathrm{C}$ for the membranes have been converted into proton conductivities $\left(\sigma_{M E M}\right)$ by means of Equation (6) and are reported in Table 4. The membranes can be ordered in terms of proton conductivity as it was observed at $60{ }^{\circ} \mathrm{C}$, that is: Nafion ${ }^{\circledR}>$ Nanocomposite crosslinked at $110^{\circ} \mathrm{C}>$ Nanocomposite crosslinked at $120^{\circ} \mathrm{C}$. Interestingly, the relative differences in conductivity between $\mathrm{Nafion}^{\circledR}$ and the nanocomposite membranes become much smaller at $120^{\circ} \mathrm{C}$ than at $60^{\circ} \mathrm{C}$. As expected, it can be concluded that SPEEK is a more suitable ionomer for fuel cell operation at intermediate temperatures, i.e. above $80^{\circ} \mathrm{C}$, which is the upper limit temperature of the Nafion ${ }^{\circledR}$ material.

Finally, it is shown in Figure 11 the simulation of the DMFC performance at $120{ }^{\circ} \mathrm{C}$ for a nanocomposite membrane crosslinked at $120^{\circ} \mathrm{C}$ if the activation 
polarization losses would be similar to the found for the MEA of the nanocomposite membrane crosslinked at $110^{\circ} \mathrm{C}$. Therefore, Equation (7) has been used with $V_{O C}$ and $R_{M E A}$ of the former but $A_{1}$ and $i_{0}$ parameters of the latter. A maximum power density of $155.8 \mathrm{~mW} \mathrm{~cm}^{-2}$ (at $520 \mathrm{~mA} \mathrm{~cm}^{-2}$ ) is obtained. This result surpasses the achieved with the Nafion ${ }^{\circledR}$ membrane and expresses the great potential of these novel nanocomposite membranes for DMFC operation at intermediate temperatures. In this regard, future studies should also focus on the optimization of the MEA preparation, e.g. with SPEEK-bound electrodes, and the favorable electrochemical activation of the electrode catalysts under intermediate temperature conditions.

$<$ Figure 9$\rangle,\langle$ Figure 10> and <Figure 11>

Table 4. Calculated parameters which fit the model of Equation (7) for the experimental $i$ - $V$ curves measured at $120^{\circ} \mathrm{C}$ with the nanocomposite membranes crosslinked at $110^{\circ} \mathrm{C}$ and $120^{\circ} \mathrm{C}$. The results of the Nafion ${ }^{\circledR} 115$ membrane are also included.

\begin{tabular}{ccccccc}
\hline Membrane & $\begin{array}{c}\text { Thickness } \\
(\boldsymbol{\mu m})\end{array}$ & $\begin{array}{c}\mathbf{V}_{\mathbf{O C}} \\
(\mathbf{V})\end{array}$ & $\begin{array}{c}\mathbf{A}_{\mathbf{1}} \\
(\mathbf{V})\end{array}$ & $\begin{array}{c}\mathbf{i}_{\mathbf{0}} \\
\left(\mathbf{A} \cdot \mathbf{c m}^{-\mathbf{2}}\right)\end{array}$ & $\begin{array}{c}\mathbf{R}_{\text {MEA }} \\
(\boldsymbol{\Omega})\end{array}$ & $\begin{array}{c}\boldsymbol{\sigma}_{\text {MEM }} \\
\left(\mathbf{S} \cdot \mathbf{c m}^{-1}\right)\end{array}$ \\
\hline Nanocomposite $\left(110^{\circ} \mathrm{C}\right)$ & $145 \pm 7$ & 0.640 & 0.050 & 7.898 & 0.126 & $(2.30 \pm 0.11) \cdot 10^{-2}$ \\
\hline Nanocomposite $\left(120^{\circ} \mathrm{C}\right)$ & $107 \pm 5$ & 0.765 & 0.065 & 2.430 & 0.099 & $(2.16 \pm 0.10) \cdot 10^{-2}$ \\
\hline Nafion $^{\circledR} 115$ & $157 \pm 2$ & 0.730 & 0.024 & 0.865 & 0.125 & $(2.51 \pm 0.03) \cdot 10^{-2}$ \\
\hline
\end{tabular}

\section{Conclusions}

Mats of proton-conducting nanofibers composed of SPEEK blended with PVB (SPEEK-30\%PVB) have been successfully obtained by electrospinning. A solution of $17.5 \mathrm{wt} \%$ polymer concentration in DMAc was found to be optimal. The conductivity of the nanofiber mats was found to exceed the conductivity of cast SPEEK-30\%PVB membranes at similar conditions. It was suggested that proton conduction in the nanofiber mats mainly takes place on the nanofiber surface, probably induced by the perpendicular orientation of the nanofiber axis towards the proton pathway.

A blend of SPEEK with PVA (SPEEK-35\%PVA), which was prepared in water as solvent, was infiltrated as a matrix phase within the nanofiber mats for the formation of novel nanocomposite membranes. The role of the solvent, i.e. water or DMAc, was observed to influence the crosslinking reaction between SPEEK and PVA. Lower crosslinking temperatures $\left(110-140^{\circ} \mathrm{C}\right)$ were required using water than DMAc (about $200^{\circ} \mathrm{C}$ ), which was explained by the polar nature and hydrogen bonding capacity of water. This observation should encourage the consideration of water as a possible solvent for the preparation of other membrane compositions.

Methanol permeability and proton conductivity of the pristine SPEEK-35\%PVA and nanocomposite membranes generally decrease with increasing crosslinking temperatures. Comparison between both type of membranes exhibited that the SPEEK$30 \%$ PVB nanofibers only benefit the nanocomposite membranes crosslinked at $110{ }^{\circ} \mathrm{C}$ and $120^{\circ} \mathrm{C}$. The methanol permeability of those membranes was reduced by the nanofibers as a consequence of a more constrained swelling and water uptake of the matrix, while proton conductivity was especially promoted by the nanofibers when crosslinking proceeded at $110^{\circ} \mathrm{C}$. No effect of the nanofibers on the conductivity was found for the membranes crosslinked at $120^{\circ} \mathrm{C}$. On the other hand, the nanofibers resulted to be detrimental for proton conductivity when the membranes were crosslinked at $130^{\circ} \mathrm{C}$ and $140^{\circ} \mathrm{C}$, which was inferred to the low proton conductivity of 
the nanofibers when water uptake diminishes. This was explained by the fact that higher crosslinking degrees are expected to modify the nanofiber-matrix interface resulting in a hindrance to proton conduction, while low crosslinking levels would enable the simultaneous occurrence of large concentrations of water molecules and sulfonic acid groups on the nanofiber surface thus promoting proton conductivity. In general, the advantages provided by the nanofibers were ascribed to their mechanical reinforcing effect which limits swelling and water uptake of the matrices with lower crosslinking degrees, in turn enhancing physical integrity of the membranes, and to their own contribution to proton conductivity. In this matter, new nanofiber compositions which can achieve high proton conductivities at low water contents are under consideration.

Experimental and simulated polarization curves obtained from DMFC tests revealed that optimized SPEEK-based nanocomposite membranes are prospective candidates to replace costly $\mathrm{Nafion}^{\circledR}$ films for DMFC application at intermediate temperatures.

\section{Acknowledgements}

This research has been funded by the R\&D Support Programmes of the Polytechnic University of Valencia (project 24761) and the Spanish Ministry of Science and Innovation (project SP-ENE-20120718).

We warmly thank the groups of both Prof. Santiago Luis (Universidad Jaume I, Castellon, Spain) and Prof. Javier Pozuelo (Universidad Carlos III, Madrid, Spain) for their valuable contributions to the measurements of IR spectroscopy and mechanical properties, respectively.

\section{References}

1. A. Carbone, R. Pedicini, G. Portale, A. Longo, L. D'Ilario, E. Passalacqua, Sulphonated poly(ether ether ketone) membranes for fuel cell application: Thermal and structural characterization, J. Power Sources 163 (2006) 18-26.

2. S.K. Kamarudin, F. Achmad, W.R.W. Daud, Overview on the application of direct methanol fuel cell (DMFC) for portable electronic devices, Int. J. Hydrogen Energ. 34 (2009) 6902-6916.

3. V. Neburchilov, J. Martin, H. Wang, J. Zhang, A review of polymer electrolyte membranes for direct methanol fuel cells, J. Power Sources 169 (2007) 221-238.

4. S. Matar, H. Liu, Effect of cathode catalyst layer thickness on methanol cross-over in a DMFC, Electrochim. Acta 56 (2010) 600-606.

5. J. Prabhuram, T.S. Zhao, H. Yang, Methanol adsorbates on the DMFC cathode and their effect on the cell performance, J. Electroanal. Chem. 578 (2005) 105-112.

6. P. Staiti, A.S. Aricò, V. Baglio, F. Lufrano, E. Passalacqua, V. Antonucci, Hybrid Nafion-silica membranes doped with heteropolyacids for application in direct methanol fuel cells, Solid State Ionics 145 (2001) 101-107.

7. P. Dimitrova, K.A. Friedrich, B. Vogt, U. Stimming, Transport properties of ionomer composite membranes for direct methanol fuel cells, J. Electroanal. Chem. 532 (2002) 75-83.

8. N. Miyake, J.S. Wainright, R.F. Savinell, Evaluation of a Sol-Gel Derived Nafion/Silica Hybrid Membrane for Polymer Electrolyte Membrane Fuel Cell Applications: II. Methanol Uptake and Methanol Permeability, J. Electrochem. Soc. 148 (2001) A905-A909. 
9. D.H. Jung, S.Y. Cho, D.H. Peck, D.R. Shin, J.S. Kim, Preparation and performance of a Nafion ${ }^{\circledR} /$ montmorillonite nanocomposite membrane for direct methanol fuel cell, J. Power Sources 118 (2003) 205-211.

10. P.-P. Lu, Z.-L. Xu, H. Yang, Y.-M. Wei, Processing-Structure-Property Correlations of Polyethersulfone/Perfluorosulfonic Acid Nanofibers Fabricated via Electrospinning from Polymer-Nanoparticle Suspensions, ACS Appl. Mater. Interfaces 4 (2012) 1716-1723.

11. Y. Li, G. He, S. Wang, S. Yu, F. Pan, H. Wu, Z. Jiang, Recent advances in the fabrication of advanced composite membranes, J. Mater. Chem. A 1 (2013) 1005810077.

12. Z.G. Shao, X. Wang, I.-M. Hsing, Composite Nafion/polyvinyl alcohol membranes for the direct methanol fuel cell, J. Membrane Sci. 210 (2002) 147-153.

13. N.W. DeLuca, Y.A. Elabd, Nafion ${ }^{\circledR} /$ poly(vinyl alcohol) blends: Effect of composition and annealing temperature on transport properties, J. Membrane Sci. 282 (2006) 217-224.

14. K.-Y. Cho, J.-Y. Eom, H.-Y. Jung, N.-S. Choi, Y.M. Lee, J.-K. Park, J.-H. Choi, K.W. Park, Y.-E. Sung, Characteristics of PVdF copolymer/Nafion blend membrane for direct methanol fuel cell (DMFC), Electrochim. Acta 50 (2004) 583-588.

15. R. Wycisk, J. Chisholm, J. Lee, J. Lin, P.N. Pintauro, Direct methanol fuel cell membranes from Nafion-polybenzimidazole blends, J. Power Sources 163 (2006) 917.

16. T. Yamaguchi, H. Zhou, S. Nakazawa, N. Hara, An Extremely Low Methanol Crossover and Highly Durable Aromatic Pore-Filling Electrolyte Membrane for Direct Methanol Fuel Cells, Adv. Mater. 19 (2007) 592-596.

17. T.H. Nguyen, X. Wang, Fabrication of the porous polyimide film as a matrix of the composite membrane of the direct methanol fuel cell, Sep. Purif. Technol. 67 (2009) 208-212.

18. L.-C. Chen, T.L. Yu, H.-L. Lin, S.-H. Yeh, Nafion/PTFE and zirconium phosphate modified Nafion/PTFE composite membranes for direct methanol fuel cells, J. Membrane Sci. 307 (2008) 10-20.

19. J. Saleem, P. Gao, J. Barford, G. McKay, Development and characterization of novel composite membranes for fuel cell applications, J. Mater. Chem. A 1 (2013) $14335-14343$.

20. T.-C. Jao, G.-B. Jung, S.-C. Kuo, W.-J. Tzeng, A. Su, Polymer electrolyte membrane water electrolyser with Aquivion ${ }^{\circledR}$ short side chain perfluorosulfonic acid ionomer binder in catalyst layers, Int. J. Hydrogen Energ. 37 (2012) 13623-13630.

21. T. Tamura, R. Takemori, H. Kawakami, Proton conductive properties of composite membranes containing uniaxially aligned ultrafine electrospun polyimide nanofiber, J. Power Sources 217 (2012) 135-141.

22. T. Tamura, H. Kawakami, Aligned electrospun nanofiber composite membranes for fuel cell electrolytes, Nano Lett. 10 (2010) 1324-1328.

23. D.M. Yu, S. Yoon, T.-H. Kim, J.Y. Lee, J. Lee, Y.T. Hong, Properties of sulfonated poly(arylene ether sulfone)/electrospun nonwoven polyacrylonitrile composite membrane for proton exchange membrane fuel cells, J. Membrane Sci. 446 (2013) 212-219.

24. C. Lee, S.M. Jo, J. Choi, K.-Y. Baek, Y.B. Truong, I.L. Kyratzis, Y.-G. Shul, $\mathrm{SiO}_{2} /$ sulfonated poly ether ether ketone (SPEEK) composite nanofiber mat supported proton exchange membranes for fuel cells, J. Mater. Sci. 48 (2013) 36653671. 
25. S.-H. Wang, H.-L. Lin, Poly (vinylidene fluoride-co-hexafluoropropylene)/ polybenzimidazole blend nanofiber supported Nafion membranes for direct methanol fuel cells, J. Power Sources 257 (2014) 254-263.

26. H.-L. Lin, S.-H. Wang, Nafion/poly(vinylalcohol) nano-fiber composite and Nafion/poly(vinylalcohol) blend membranes for direct methanol fuel cells, J. Membrane Sci. 452 (2014) 253-262.

27. M.M. Hasani-Sadrabadi, I. Shabani, M. Soleimani, H. Moaddel, Novel nanofiberbased triple-layer proton exchange membranes for fuel cell applications, J. Power Sources 196 (2011) 4599-4603.

28. I. Shabani, M.M. Hasani-Sadrabadi, V. Haddadi-Asl, M. Soleimani, Nanofiberbased polyelectrolytes as novel membranes for fuel cell applications, J. Membrane Sci. 368 (2011) 233-240.

29. J. Choi, K.M. Lee, R. Wycisk, P.N. Pintauro, P.T. Mather, Nanofiber Network IonExchange Membranes, Macromolecules 41 (2008) 4569-4572.

30. J. Choi, K.M. Lee, R. Wycisk, P.N. Pintauro, P.T. Mather, Sulfonated Polysulfone/POSS Nanofiber Composite Membranes for PEM Fuel Cells, J. of The Electrochem. Soc. 157 (2010) B914-B919.

31. B. Dong, L. Gwee, D. Salas-de la Cruz, K.I. Winey, Y.A. Elabd, Super Proton Conductive High-Purity Nafion Nanofibers, Nano Lett. 10 (2010) 3785-3790.

32. Z. Hongwei, Y. Fei, Z. Danying, Fabrication and characterization of electrospun sulfonated poly(phthalazinone ether ketone) mats as potential matrix of reinforced proton exchange membranes, J. Appl. Polym. Sci. 130 (2013) 4581-4586.

33. J. Zhang, Y. Wang, Modeling the Effects of Methanol Crossover on the DMFC, Fuel Cells 4 (2004) 90-95.

34. G.-B. Jung, A. Su, C.-H. Tu, F.-B. Weng, Effect of Operating Parameters on the DMFC Performance, J. Fuel Cell Sci. Tech. 2 (2005) 81-85.

35. J.G. Liu, T.S. Zhao, Z.X. Liang, R. Chen, Effect of membrane thickness on the performance and efficiency of passive direct methanol fuel cells, J. Power Sources 153 (2006) 61-67.

36. H.-Y. Li, Y.-L. Liu, Nafion-functionalized electrospun poly(vinylidene fluoride) (PVDF) nanofibers for high performance proton exchange membranes in fuel cells, J. Mater. Chem. A 2 (2014) 3783-3793.

37. S. Mollá, V. Compañ, Polyvinyl alcohol nanofiber reinforced Nafion membranes for fuel cell applications, J. Membrane Sci. 372 (2011) 191-200.

38. S. Mollá, V. Compañ, Performance of composite Nafion/PVA membranes for direct methanol fuel cells, J. Power Sources 196 (2011) 2699-2708.

39. S. Mollá, V. Compañ, E. Gimenez, A. Blazquez, I. Urdanpilleta, Novel ultrathin composite membranes of Nafion/PVA for PEMFCs, Int. J. Hydrogen Energ. 36 (2011) 9886-9895.

40. Q. Li, R. He, J.O. Jensen, N.J. Bjerrum, Approaches and Recent Development of Polymer Electrolyte Membranes for Fuel Cells Operating above $100{ }^{\circ} \mathrm{C}$, Chem. Mater. 15 (2003) 4896-4915.

41. Y. Shao, G. Yin, Z. Wang, Y. Gao, Proton exchange membrane fuel cell from low temperature to high temperature: Material challenges, J. Power Sources 167 (2007) 235-242.

42. S. Mollá, V. Compañ, Polymer blends of SPEEK for DMFC application at intermediate temperatures, Int. J. Hydrogen Energ. 39 (2014) 5121-5136.

43. S. Mollá, V. Compañ, S.L. Lafuente, J. Prats, On methanol Permeability through Pristine Nafion ${ }^{\circledR}$ and Nafion/PVA Membranes Measured by Different Techniques. A comparison of Methodologies, Fuel Cells 11 (2011) 897-906. 
44. P.W. Majsztrik, M.B. Satterfield, A.B. Bocarsly, J.B. Benziger, Water sorption, desorption and transport in Nafion membranes, J. Membrane Sci. 301 (2007) 93106.

45. M. Bass, V. Freger, Hydration of Nafion and Dowex in liquid and vapor environment: Schroeder's paradox and microstructure, Polymer 49 (2008) 497-506.

46. T. Romero, W. Mérida, Water transport in liquid and vapour equilibrated Nafion ${ }^{\mathrm{TM}}$ membranes, J. Membrane Sci. 338 (2009) 135-144.

47. S. Ramakrishna, K. Fujihara, W.-E. Teo, T.-C. Lim, Z. Ma, in: An Introduction to Electrospinning and Nanofibers, World Scientific Publishing Co., 2005 (Chapter 3).

48. X. Zhang, Y. Lu, Centrifugal Spinning: An Alternative Approach to Fabricate Nanofibers at High Speed and Low Cost, Polym. Rev. 54 (2014) 677-701.

49. D. Marx, M.E. Tuckerman, J. Hutter, M. Parrinello, The nature of the hydrated excess proton in water, Nature 397 (1999) 601-604.

50. J. Roziere, D.J. Jones, Non-fluorinated polymer materials for proton exchange membrane fuel cells, Annu. Rev. Mater. Res. 33 (2003) 503-555.

51. R. Jiang, H.R. Kunz, J.M. Fenton, Investigation of membrane property and fuel cell behavior with sulfonated poly(ether ether ketone) electrolyte: Temperature and relative humidity effects, J. Power Sources 150 (2005) 120-128.

52. L. Li, J. Zhang, Y. Wang, Proton conductivity of phosphoric acid doped polybenzimidazole and its composites with inorganic proton conductors, J. Membrane Sci. 226 (2003) 159-167.

53. X. Li, C. Zhao, H. Lu, Z. Wang, H. Na, Direct synthesis of sulfonated poly(ether ether ketone ketone)s (SPEEKKs) proton exchange membranes for fuel cell application, Polymer 46 (2005) 5820-5827.

54. T.J. Peckham, S. Holdcroft, Structure-Morphology-Property Relationships of NonPerfluorinated Proton-Conducting Membranes, Adv. Mater. 22 (2010) 4667-4690.

55. H.L. Tang, M. Pan, F. Wang, A mechanical durability comparison of various perfluocarbon proton exchange membranes, J. Appl. Polym. Sci. 109 (2008) 26712678.

56. W.R. Bowen, T.A. Doneva, H.B. Yin, Polysulfone-sulfonated poly(ether ether) ketone blend membranes: systematic synthesis and characterization, J. Membrane Sci. 181 (2001) 253-263.

57. T. He, M. Frank, M.H.V. Mulder, M. Wessling, Preparation and characterization of nanofiltration membranes by coating polyethersulfone hollow fibers with sulfonated poly(ether ether ketone) (SPEEK), J. Membrane Sci. 307 (2008) 62-72.

58. W.J. Lau, A.F. Ismail, Theoretical studies on the morphological and electrical properties of blended PES/SPEEK nanofiltration membranes using different sulfonation degree of SPEEK, J. Membrane Sci. 334 (2009) 30-42.

59. J.M. Gohil, P. Ray, Polyvinyl alcohol as the barrier layer in thin film composite nanofiltration membranes: Preparation, characterization, and performance evaluation, J. Colloid Interf. Sci. 338 (2009) 121-127.

60. T. Yang, Preliminary study of SPEEK/PVA blend membranes for DMFC applications, Int. J. Hydrogen Energ. 33 (2008) 6772-6779.

61. J. Jaafar, A.F. Ismail, A. Mustafa, Preparation of High Performance SPEEK/Cloisite 15A Nanocomposite Membrane via Advanced Membrane Formulation Method, Mater. Sci. Eng. A 460-461 (2007) 475-484.

62. S. Gu, G. He, X. Wu, Y. Guo, H. Liu, L. Peng, G. Xiao, Preparation and characteristics of crosslinked sulfonated poly(phthalazinone ether sulfone ketone) with poly(vinyl alcohol) for proton exchange membrane, J. Membrane Sci. 312 (2008) 48-58. 
63. X. Li, X. Hao, D. Xu, G. Zhang, S. Zhong, H. Na, D. Wang, Fabrication of sulfonated poly(ether ether ketone ketone) membranes with high proton conductivity, J. Membrane Sci. 281 (2006) 1-6.

64. H.-L. Lin, T.L. Yu, L.-N. Huang, L.-C. Chen, K.-S. Shen, G.-B. Jung, Nafion/PTFE composite membranes for direct methanol fuel cell applications, J. Power Sources 150 (2005) 11-19.

65. A.M. Affoune, A. Yamada, M. Umeda, Conductivity and surface morphology of Nafion membrane in water and alcohol environments, J. Power Sources 148 (2005) 9-17.

66. X. Dominguez-Benetton, S. Sevda, K. Vanbroekhoven, D. Pant, The accurate use of impedance analysis for the study of microbial electrochemical systems, Chem. Soc. Rev. 41 (2012) 7228-7246.

67. J. Zhang, Z. Xie, J. Zhang, Y. Tang, C. Song, T. Navessin, Z. Shi, D. Song, H. Wang, D.P. Wilkinson, Z.-S. Liu, S. Holdcroft, High temperature PEM Fuel Cells, J. Power Sources 160 (2006) 872-891.

\section{FIGURE CAPTIONS}

Fig. 1. SEM images of electrospun nanofibers prepared from SPEEK-30\%PVB solutions under the same electrospinning conditions but different polymer concentrations: (a) 12.5 wt\% (magnified x1,000); (b) 15 wt\% (x1,000); (c) 17.5 wt\% (x1,000); and (d) 20 wt\% (x750).

Fig. 2. SEM images of SPEEK-30\%PVB nanofibers crosslinked at $200^{\circ} \mathrm{C}$ : (a) As-produced (magnified $\times 2,000$ ); and (b) after 1 hour immersion in boiling water $(\mathrm{x} 2,000)$.

Fig. 3. SEM images of a sample of nanocomposite membrane containing SPEEK-30\%PVB nanofibers within a SPEEK-35\%PVA matrix: (a) View of the surface (magnified $\times 1,000$ ); and (b) cross-section revealing outer layers of pure SPEEK-35\%PVA and an inner nanofiber-reinforced layer (x2,000).

Fig. 4. FTIR spectra as a function of crosslinking temperature for SPEEK$35 \%$ PVA membranes prepared from aqueous solutions: (Black) as-prepared, (grey) crosslinked at $120^{\circ} \mathrm{C}$, and (light grey) crosslinked at $140^{\circ} \mathrm{C}$.

Fig. 5. Profiles of methanol concentration in receptor chamber versus time measured at $60{ }^{\circ} \mathrm{C}$ from a $2 \mathrm{M}$ aqueous methanol solution in donor chamber, which have been obtained for the nanocomposite membranes depending on crosslinking temperature and membrane thickness: (घ) $110^{\circ} \mathrm{C}, 145 \mu \mathrm{m}$; (•) $120^{\circ} \mathrm{C}, 107 \mu \mathrm{m} ;(\boldsymbol{\Delta}) 130{ }^{\circ} \mathrm{C}, 88 \mu \mathrm{m}$; and $(\boldsymbol{\nabla}) 140{ }^{\circ} \mathrm{C}, 71 \mu \mathrm{m}$.

Fig. 6. Representation of the apparent methanol permeabilities at $60 \stackrel{\circ}{\mathrm{C}}$ for (closed symbol) SPEEK-35\%PVA and (open symbol) nanocomposite membranes in relation to their crosslinking temperatures. The value measured for a commercial Nafion ${ }^{\circledR} 115$ membrane is included for reference.

Fig. 7. Bode diagram showing the proton conductivity profiles at $90 \stackrel{\circ}{\mathrm{C}}$ of a (square) SPEEK-30\%PVB nanofiber mat (283 $\mu \mathrm{m}$ thick) with embedded Milli-Q water, and a (circle) SPEEK-30\%PVB membrane (260 $\mu \mathrm{m}$ thick) prepared by 
casting. Real conductivity and phase angle are represented by solid and open symbols, respectively.

Fig. 8. Proton conductivities at $90 \stackrel{\circ}{\mathrm{C}}$ for (closed symbol) SPEEK-35\%PVA and (open symbol) nanocomposite membranes as a function of crosslinking temperature. The result of a commercial Nafion ${ }^{\circledR} 115$ membrane was $5.90 \cdot 10^{-}$ ${ }^{2} \mathrm{~S} \mathrm{~cm}^{-1}$ (not shown in graphic).

Fig. 9. DMFC performance of the (a) nanocomposite membrane crosslinked at $110 \stackrel{\circ}{ } \mathrm{C}\left(145 \mu \mathrm{m}\right.$ thick), (b) nanocomposite membrane crosslinked at $120 \stackrel{\circ}{ }{ }^{\circ} \mathrm{C}$ (107 $\mu \mathrm{m}$ thick), and (c) Nafion ${ }^{\circledR} 115$ membrane (157 $\mu \mathrm{m}$ thick) measured at

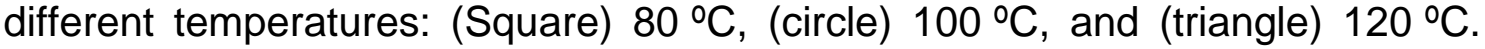
Cell voltage profiles are represented by solid symbols and power density curves by open symbols.

Fig. 10. Fitting between (black line) experimental and (grey line) modeled profiles corresponding to the DMFC performance at $120{ }^{\circ} \mathrm{C}$ of the (a) nanocomposite membrane crosslinked at $110^{\circ} \mathrm{C}$, (b) nanocomposite membrane crosslinked at $120 \stackrel{\circ}{\circ}$, and (c) Nafion ${ }^{\circledR} 115$ membrane. Left charts describe the cell voltage profiles (i-V) and right charts represent corresponding power density curves versus current density (i-P).

Fig. 11. Simulation of the (black line) $\mathrm{i}-\mathrm{V}$ and (grey line) power density results for the DMFC performance at $120 \stackrel{\circ}{\circ}$ of the nanocomposite membrane crosslinked at $120^{\circ} \mathrm{C}$ if polarization losses are assumed to be similar to the exhibited by the nanocomposite membrane crosslinked at $110^{\circ} \mathrm{C}$. 


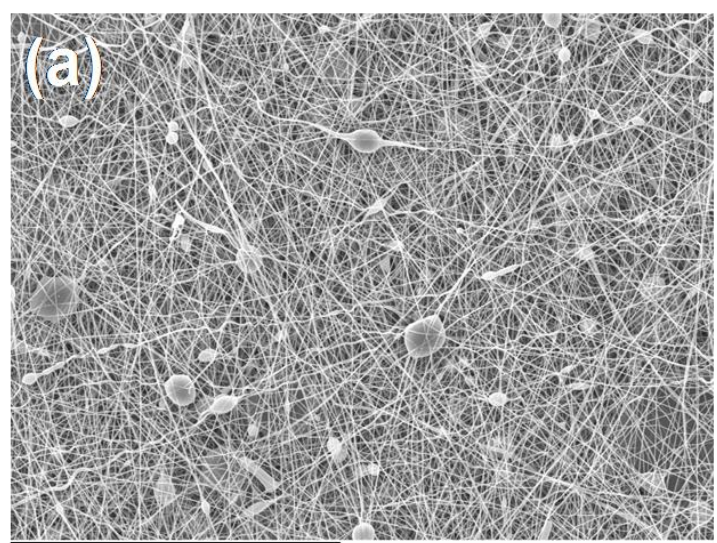

$60 \mu \mathrm{m}$

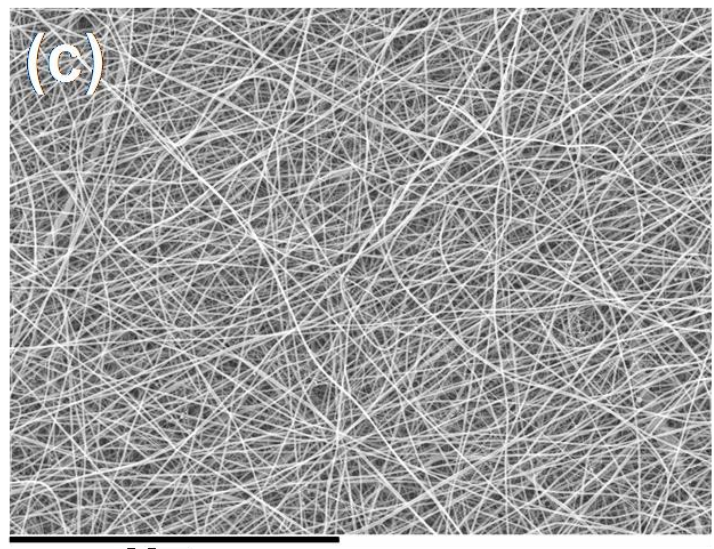

$60 \mu \mathrm{m}$

\section{Figure 1}

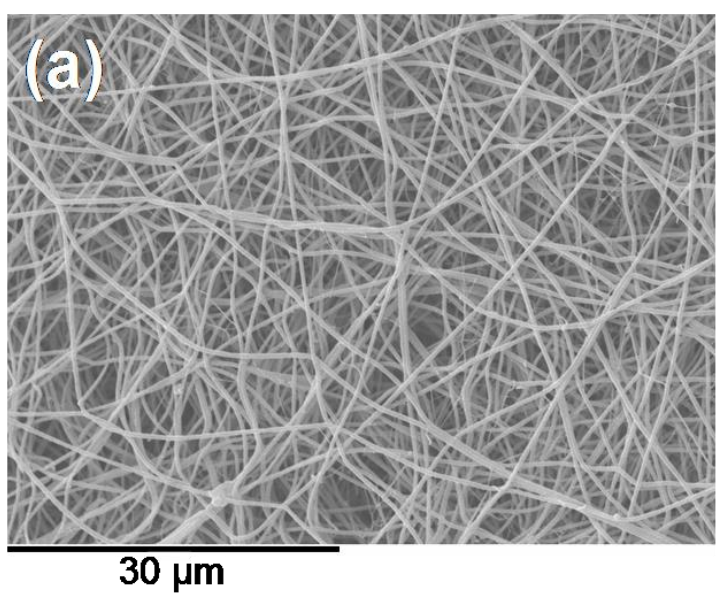

Figure 2.

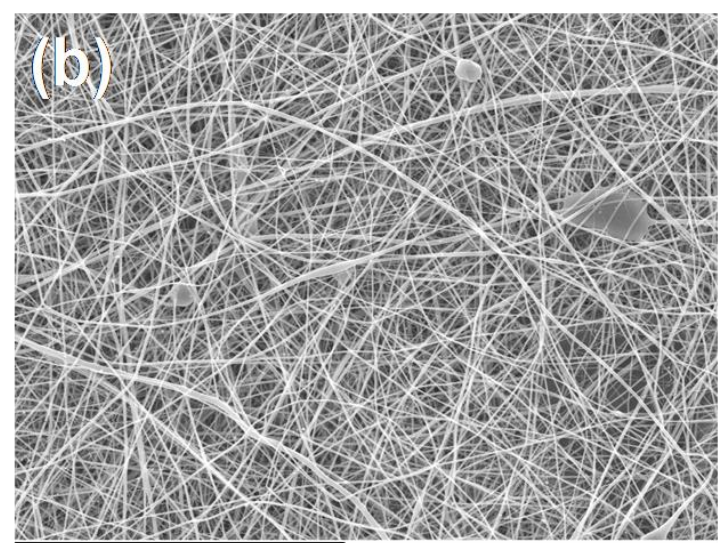

\section{$60 \mu \mathrm{m}$}

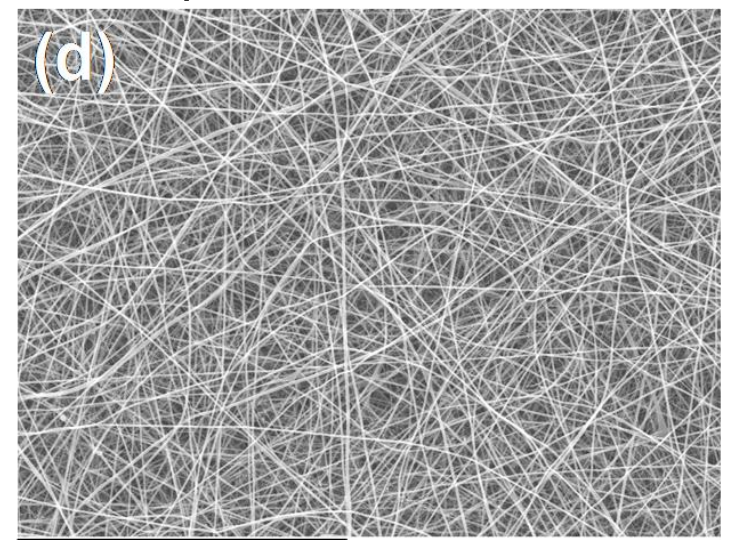

$80 \mu \mathrm{m}$

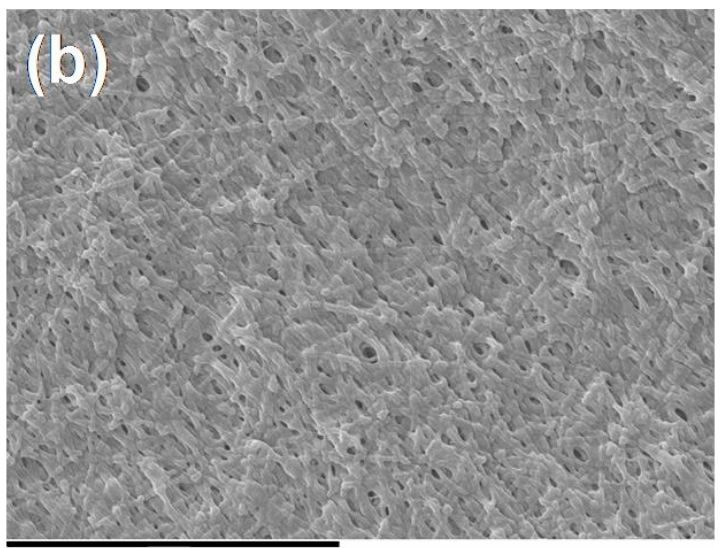

$30 \mu \mathrm{m}$ 


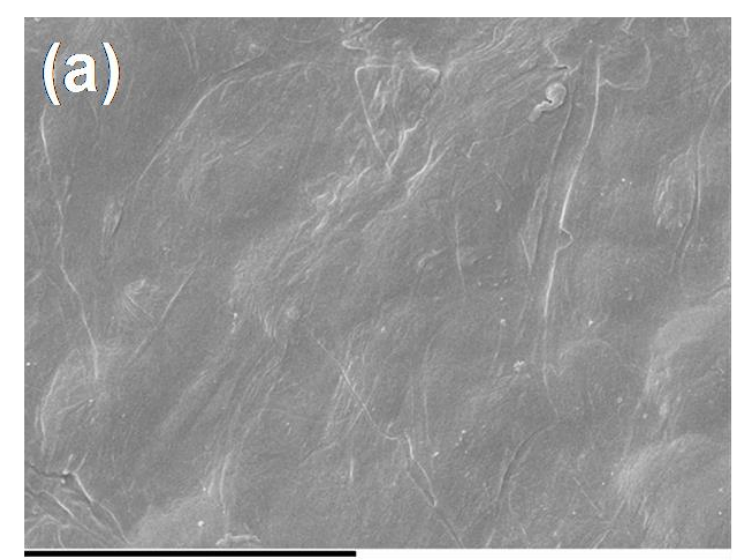

$60 \mu \mathrm{m}$

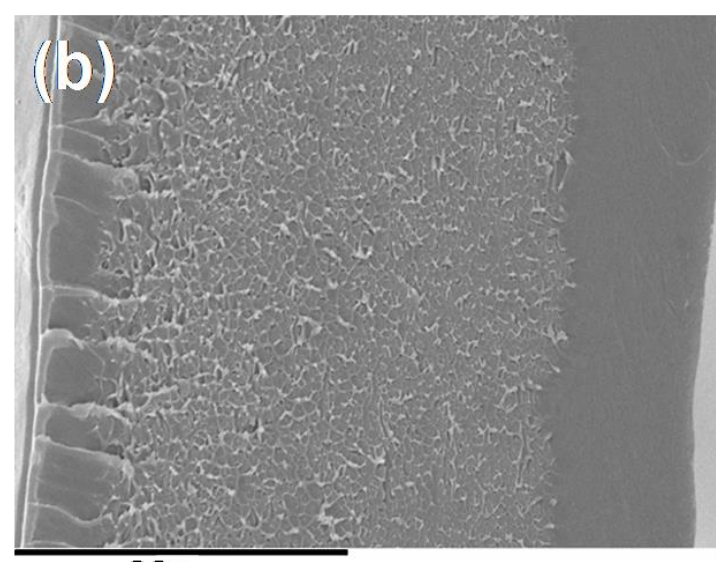

$30 \mu \mathrm{m}$

Figure 3

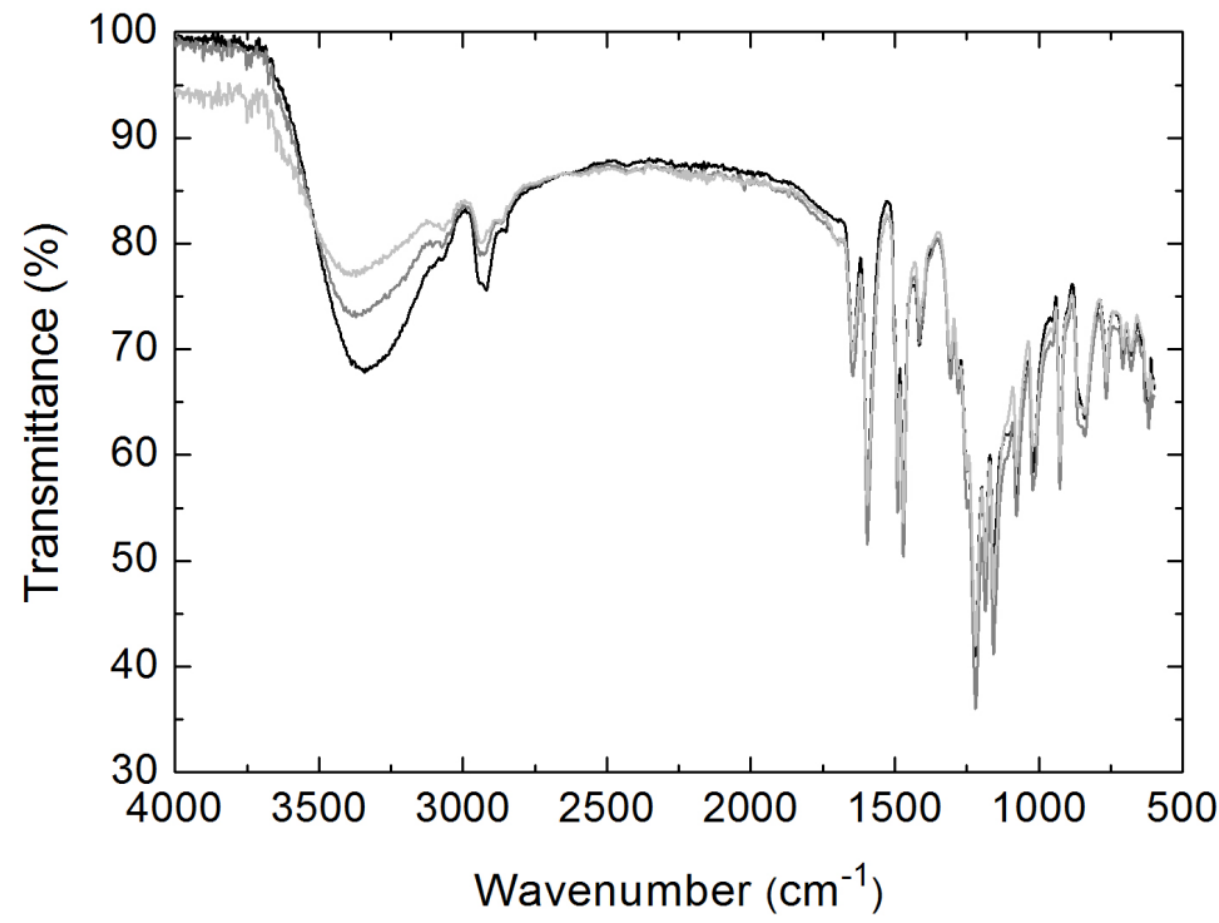

Figure 5 


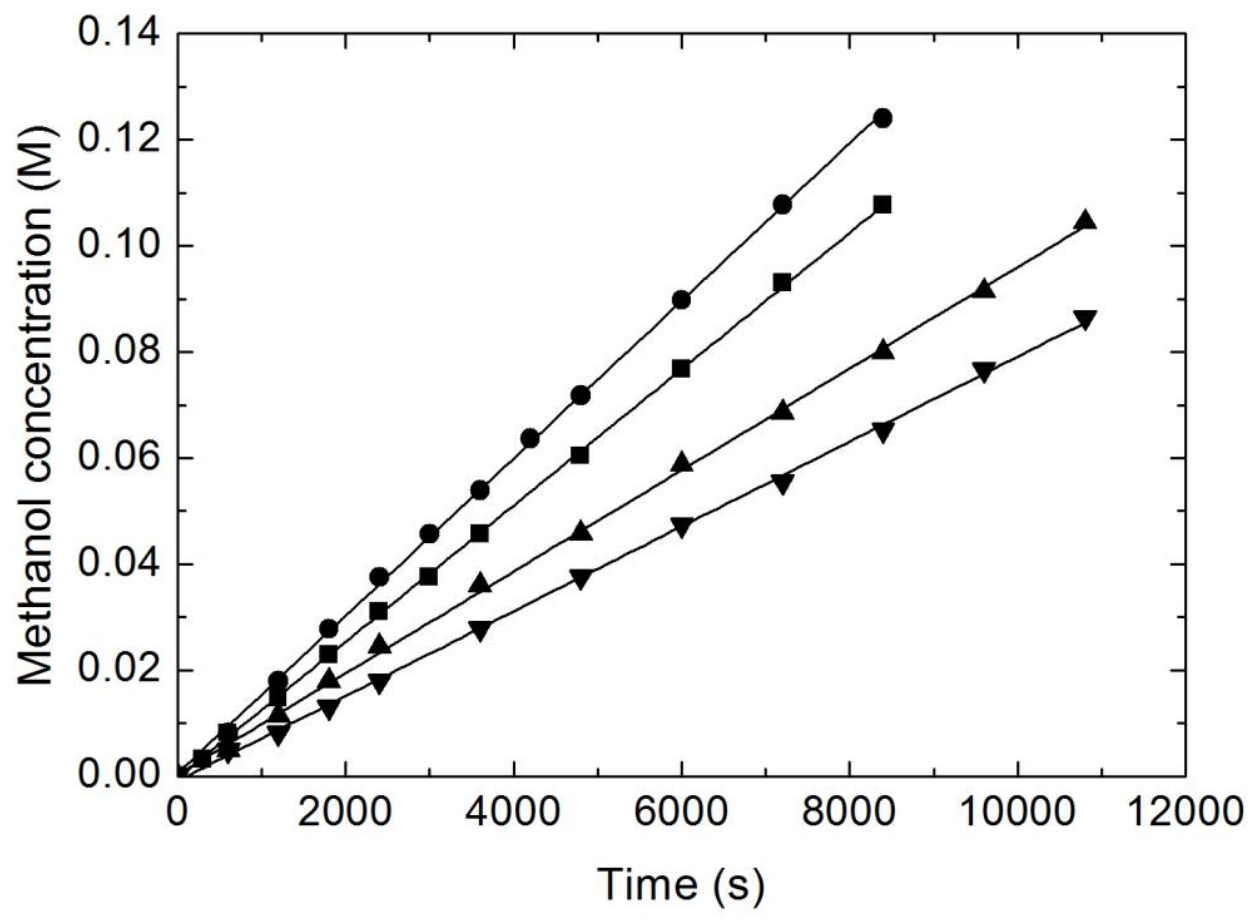

Figure 5.

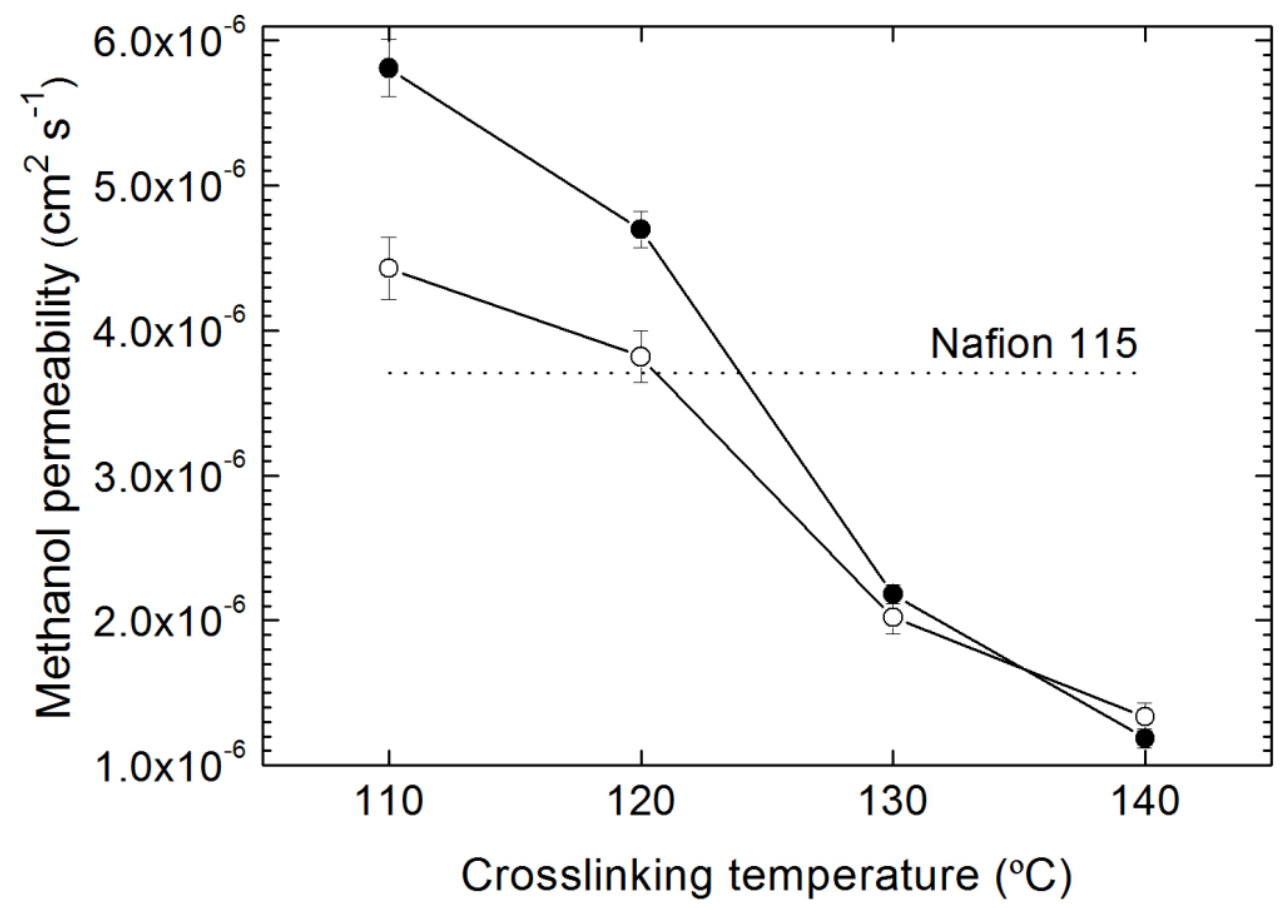

Figure 6 


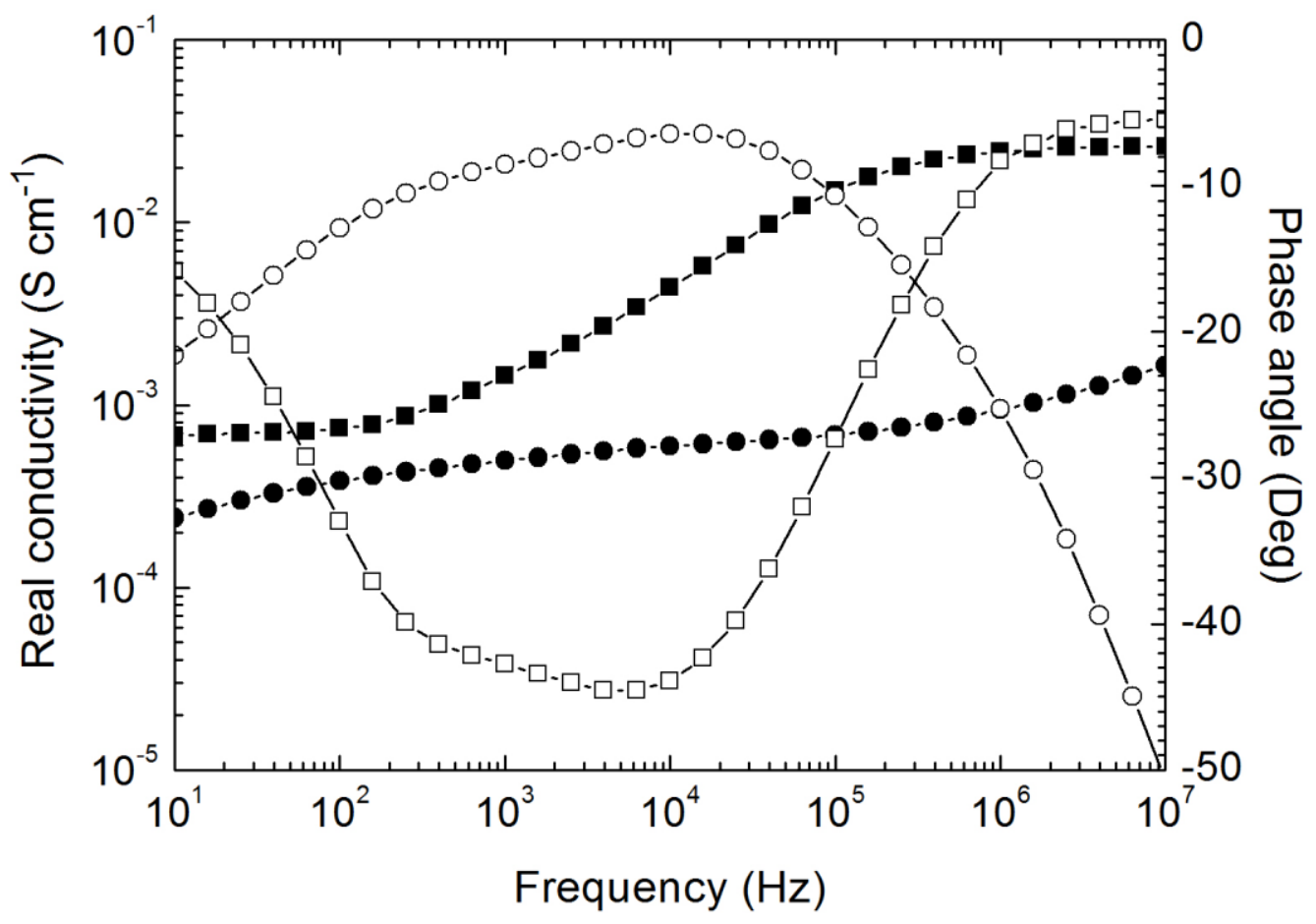

Figure 7.

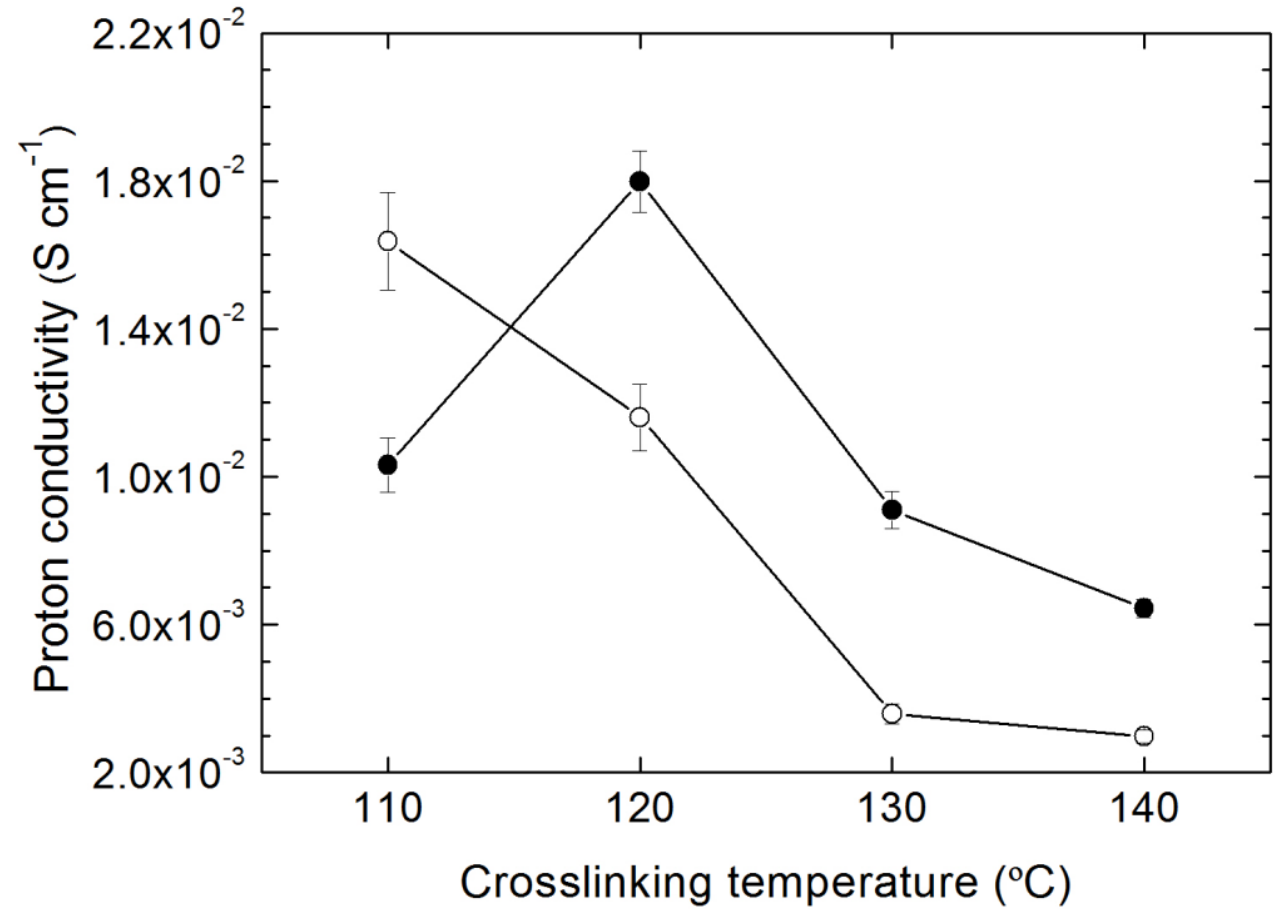

Figure 8 

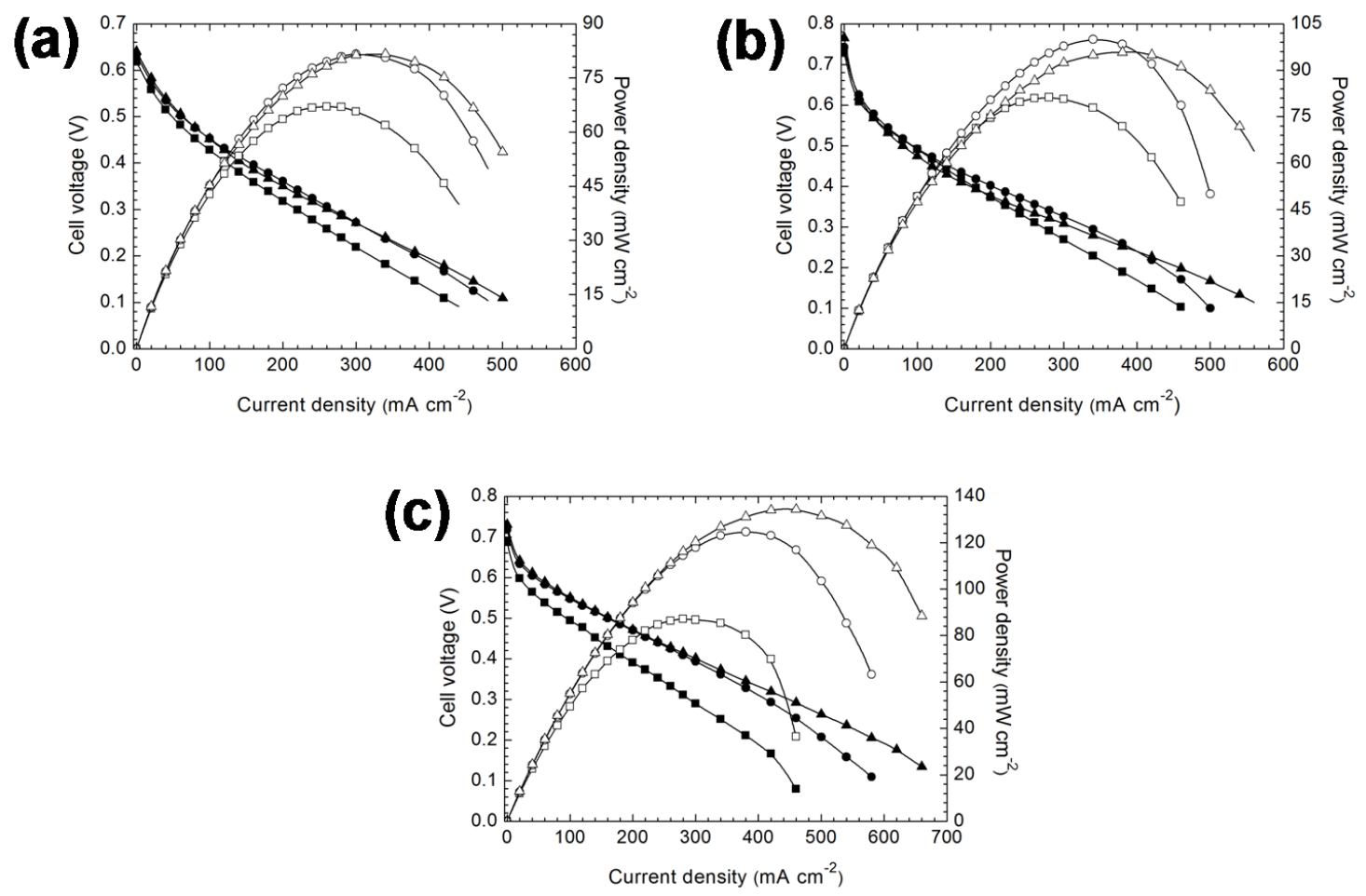

Figure 9. 
(a)

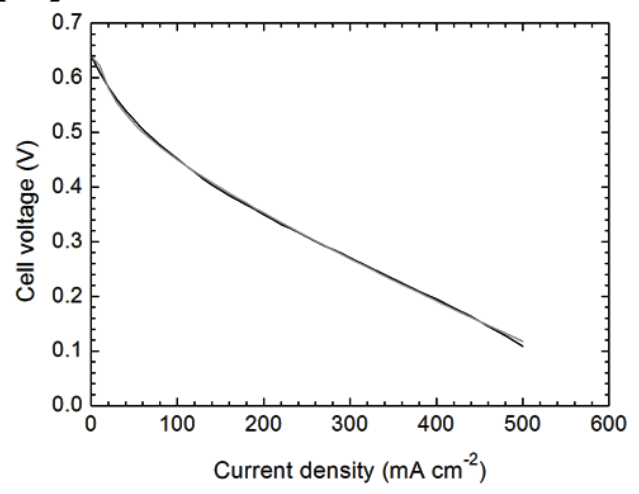

(b)

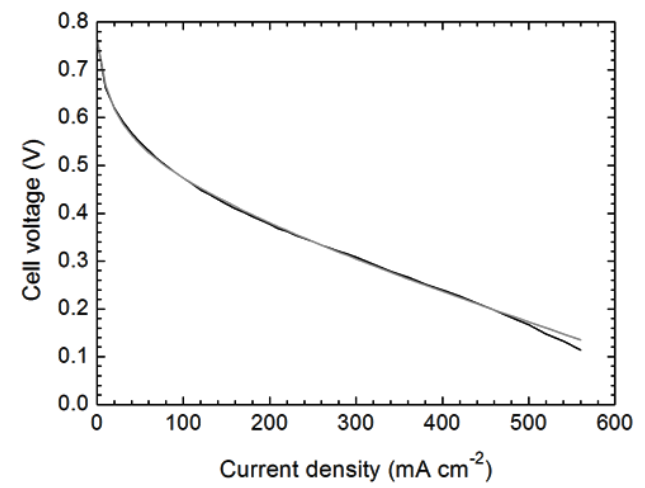

(c)

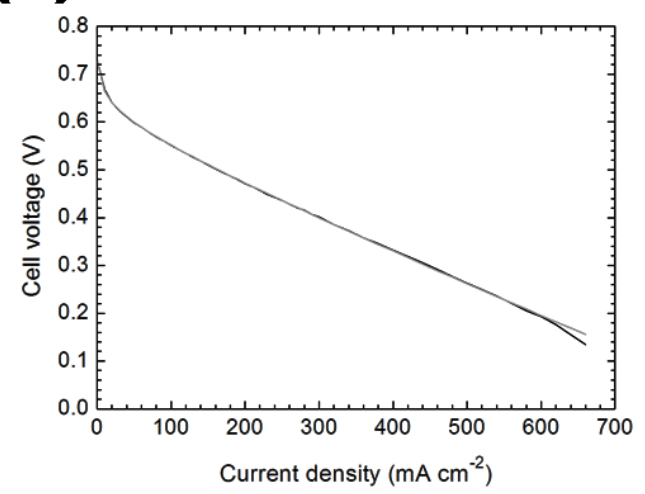

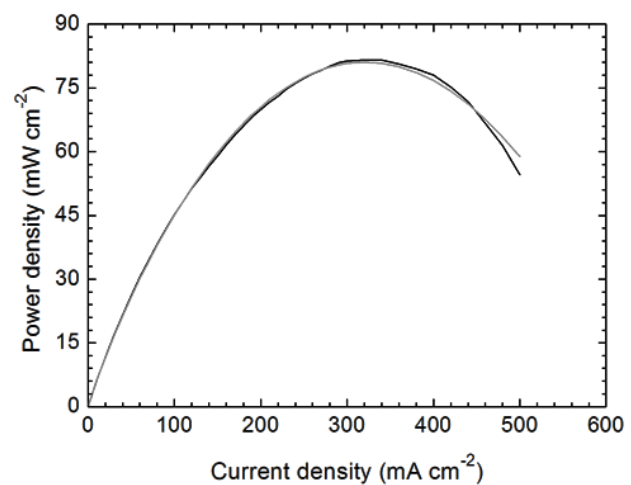
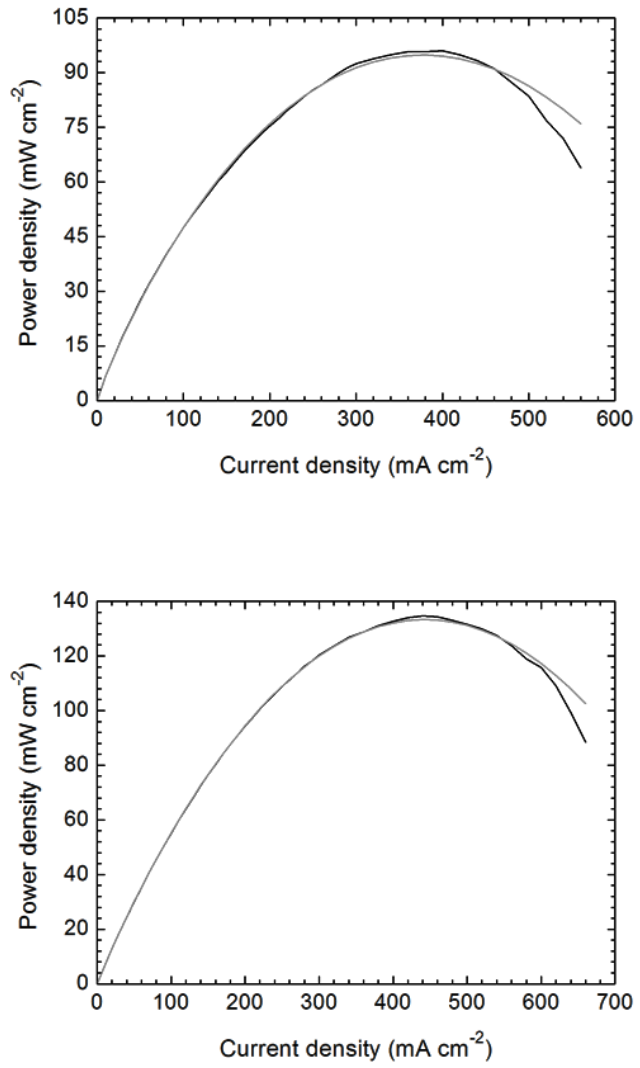

Figure 10 


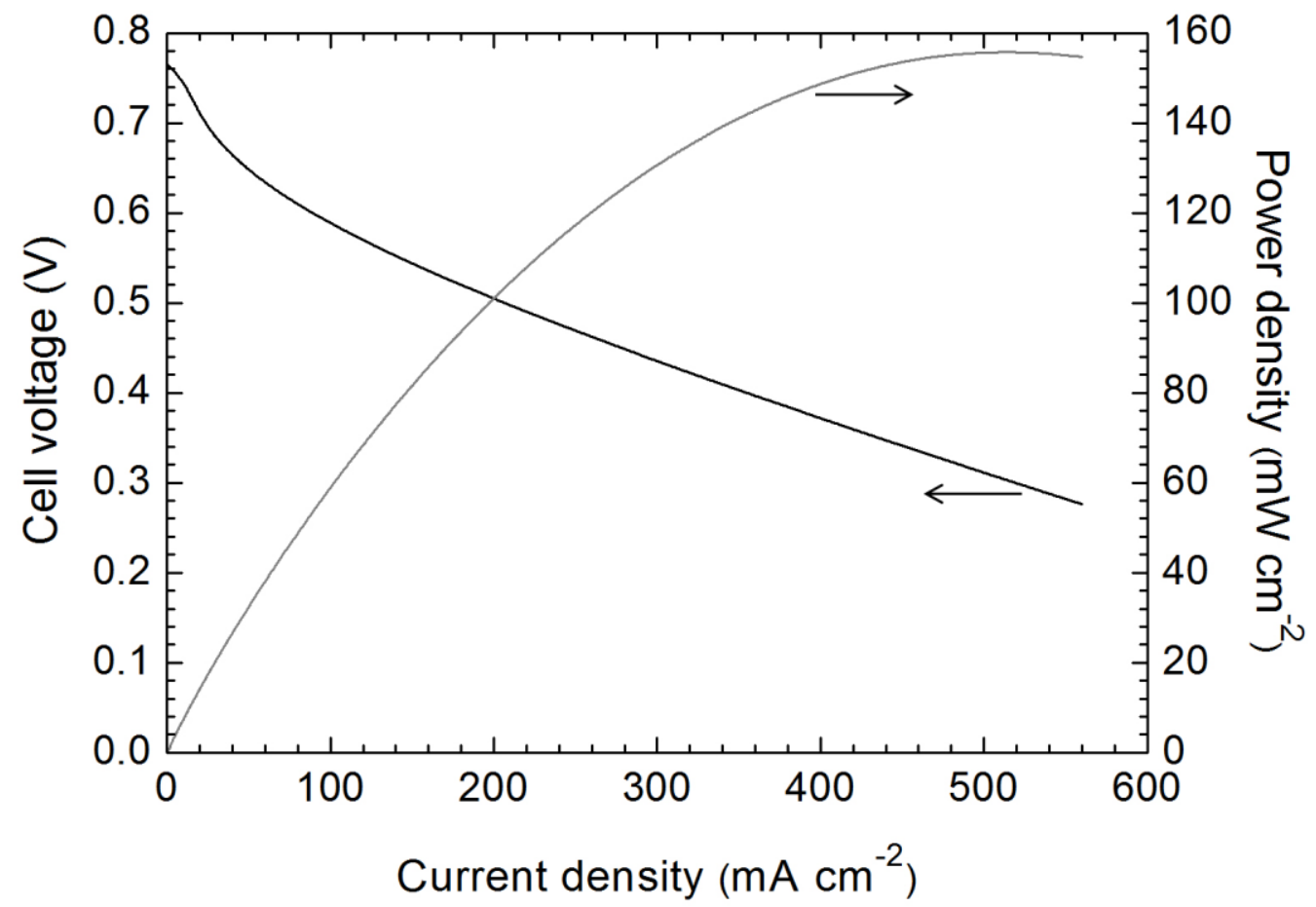

Figure 11. 